\title{
Lithology and Subdivisions of the Jurassic Stump Formation in Southeastern Idaho and Adjoining Areas
}

GEOLOGICAL SURVEY PROFESSIONAL PAPER 1035-C
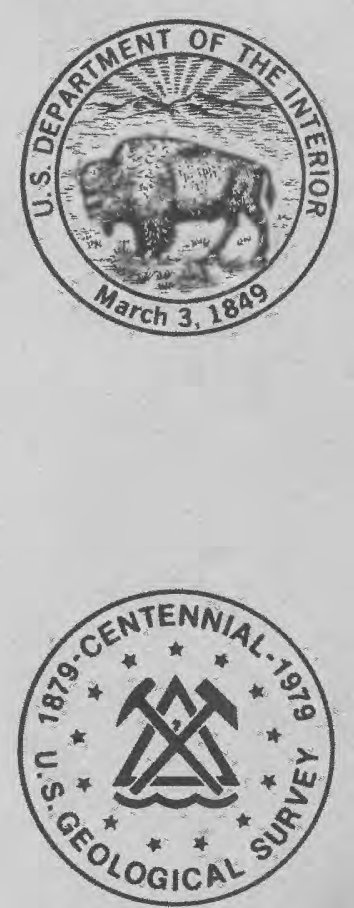



\section{Lithology and Subdivisions of the Jurassic Stump Formation in Southeastern Idaho and Adjoining Areas}

By GEORGE N. PIPIRINGOS and RALPH W. IMLAY

UNCONFORMITIES, CORRELATION, AND NOMENCLATURE OF SOME TRIASSIC AND JURASSIC ROCKS, WESTERN INTERIOR UNITED STATES

GEOLOGICAL SURVEY PROFESSIONAL PAPER 1035-C

Marked rapid lateral changes in lithology, fossil content, and thickness of the Stump Formation are due principally to erosion associated with the Cretaceous $(K)$ and Jurassic $(J-4)$ unconformities
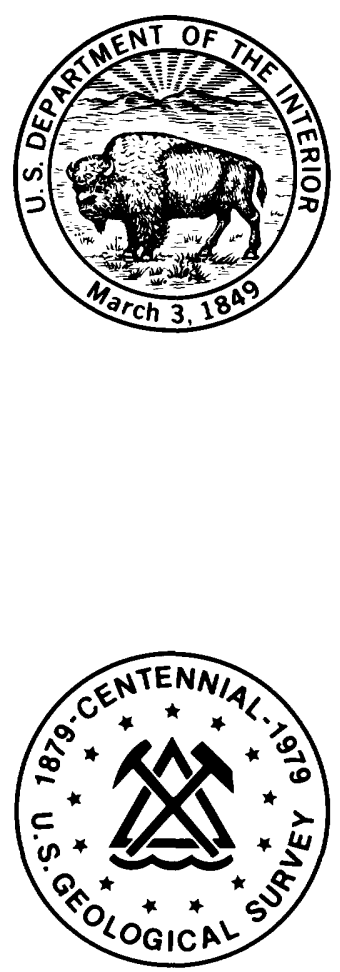

UNITED STATES GOVERNMENT PRINTING OFFICE, WASHINGTON : 1979 


\title{
UNITED STATES DEPARTMENT OF THE INTERIOR
}

\author{
CECIL D. ANDRUS, Secretary
}

\section{GEOLOGICAL SURVEY}

H. William Menard, Director

Library of Congress Cataloging in Publication Data

Pipiringos, George Nicholas, $1918-$

Lithology and subdivisions of the Jurassic stump formation in southeastern Idaho and adjoining areas.

(Unconformities, correlation, and nomenclature of some Triassic and Jurassic rocks, western interior

United States) (Geological Survey Professional Paper 1035-C)

Bibliography: p. 25

1. Geology, Stratigraphic-Jurassic. 2. Geology-Idaho. 3. Geology-The West. 4. Petrology-Idaho.

5. Petrology-The West. I. Imlay, Ralph Willard, 1908-joint author. II. Title. III. Series. IV. Series:

United States Geological Survey Professional Paper 1035-C.

QE681.P49 551.7'6 78-1687

For sale by the Superintendent of Documents, U.S. Government Printing Office

Washington, D.C. 20402

Stock Number 024-001-03150-7 


\section{CONTENTS}

Abstract $\ldots \ldots \ldots \ldots$
Introduction $\ldots \ldots \ldots \ldots$

\section{ILLUSTRATIONS}

FigliRE 1. Index map of the Western United States, showing distribution of Stump Formation ...........................................

2. Index map of southeastern Idaho, western Wyoming, and northern Utah, showing location of measured sections of the

Stump Formation

3. Index map of southeastern Idaho and adjoining areas showing approximate margin of the Redwater Member of the Stump Formation

4. Columnar sections of the Stump Formation from Wolverine Canyon, Idaho to Watton Canyon, Utah

5. Columnar sections of the Stump Formation from Blacktail Creek, Idaho to Telephone Creek. Wyoming ....................

6. Columnar sections of the Stump Formation from Sheep Creek, Wyoming to Peoa, Utah

7-16. Photographs showing:

7. Contact of the Stump Formation with the Preuss Sandstone at Indian Camp Hollow (loc. 3, fig. 5)

8. Stump Formation at McCoy Creek (loc. 4, fig. 5)

9. Sandstone unit of the Curtis Member at the start of Corral Creek trail (loc. 5, fig. 5)

10. Type area of the Stump Formation

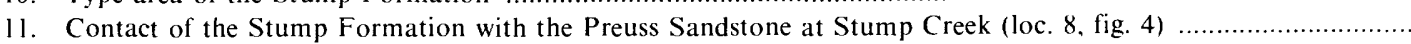

12. Ephraim Conglomerate, Stump Formation and Preuss Sandstone at Telephone Creek section (loc. 9, fig. 5) .....

13. Ephraim Conglomerate, Stump Formation. Preuss Sandstone, and Twin Creek Limestone near junction of Sheep Creek with Greys River (loc. 10, fig. 6)

14. Bedding features typical of the Curtis Member, sandstone unit of the Stump Formation

15. Stump Formation on old U.S. Highway 30 near Evanston, Wyoming (loc. 17, fig. 6)

16. Near view of contacts shown in figure $15 B$

\section{TABLE}





\title{
UNCONFORMITIES, CORRELATION, AND NOMENCLATURE OF SOME TRIASSIC AND JURASSIC ROCKS, WESTERN INTERIOR UNITED STATES
}

\section{LITHOLOGY AND SUBDIVISIONS OF THE JURASSIC STUMP FORMATION IN SOUTHEASTERN IDAHO AND ADJOINING AREAS}

\author{
By George N. Pipiringos and Ralph W. Imlay
}

\section{ABSTRACT}

\begin{abstract}
The Stump Formation (called Stump Sandstone in previous reports) comprises the latest marine Jurassic beds near the Idaho-Wyoming border and adjoining parts of $U$ tah, and it is divisible into two members. The lowest member is nearly identical with the Curtis Formation of Utah, and the upper member closely resembles and contains the same fossils as the sandy facies of the Redwater Shale Member of the Sundance Formation of Wyoming. The Stump Formation is herein divided from about the Salt Lake City area north through the Wyoming-Idaho thrust belt and east in the Uinta Mountains as far as northwest Colorado into the Middle Jurassic Curtis Member, which is reduced in stratigraphic rank in these areas from formation, and the Upper Jurassic Redwater Member, which is newly assigned to the Stump in these areas. The stratigraphic and geographic relations of the two members show that they were deposited in different seas that covered difterent areas, that erosion occurred before and after Redwater deposition, and that variations in the thicknesses of the members are in part depositional but are due principally to truncation of stratigraphic units directly under the Cretaceous $(\mathrm{K})$ and Jurassic $(\mathrm{J}-4)$ unconformities.
\end{abstract}

\section{INTRODUCTION}

This report discusses the lithologic characteristics, subdivisions, areal distribution, ages, and correlations of the latest marine Jurassic beds, called the Stump Formation, as exposed along the Wyoming-Idaho border and nearby in northern Utah. One principal and two supplementary reference sections are herewith established, and 18 stratigraphic sections are described, based on field studies by the writers in 1975 and 1976. The regional distribution of the Middle and Upper Jurassic Stump Formation in the Western United States, shown in figure 1, is nearly the same as that of the Middle Jurassic Twin Creek Limestone as shown by Imlay (1967, p. 54). Locations of measured stratigraphic sections as well as localities mentioned in the text are shown in figures 1,2, and 3. Stratigraphic sections described at the end of the report are shown graphically in figures 4,5 , and 6 . Localities in figure 4 lie west and localities in figures 5 and 6 lie east of the line representing the approximate western margin of the Redwater Member of the Stump Formation shown in figure 3.

Figures 7 through 16 are representative of the lithologic features and general appearance of the Stump Formation throughout the study area.

Thickness of the Stump Formation and its various subdivisions are summarized in table 1 from measured sections described in the section entitled "Stratigraphic sections."

\section{STUMP FORMATION}

The term Stump Formation includes the latest Jurassic marine sandstone, limestone, sandy shale, siltstone, and claystone overlying the red Middle Jurassic Preuss Sandstone in westernmost Wyoming, southeastern Idaho, and adjoining parts of northern Utah. Stump Formation is used in place of Stump Sandstone because sandstone is not the predominant rock type in all sections and because several other kinds of sedimentary rocks are present in most sections. The formation occurs in an area extending from the Blackfoot Mountains southeast of Idaho Falls eastward to the Hoback Range and Wyoming Range in western Wyoming and extending from the Snake River Range southward at least as far as Woodruff and Peoa in north-central Utah (fig. 2). Its distribution coincides mainly with a belt of overthrusting that extends along the Wyoming-ldaho border southward into north-central Utah, but it occurs also in the Uinta Mountains in northeastern Utah east of the 


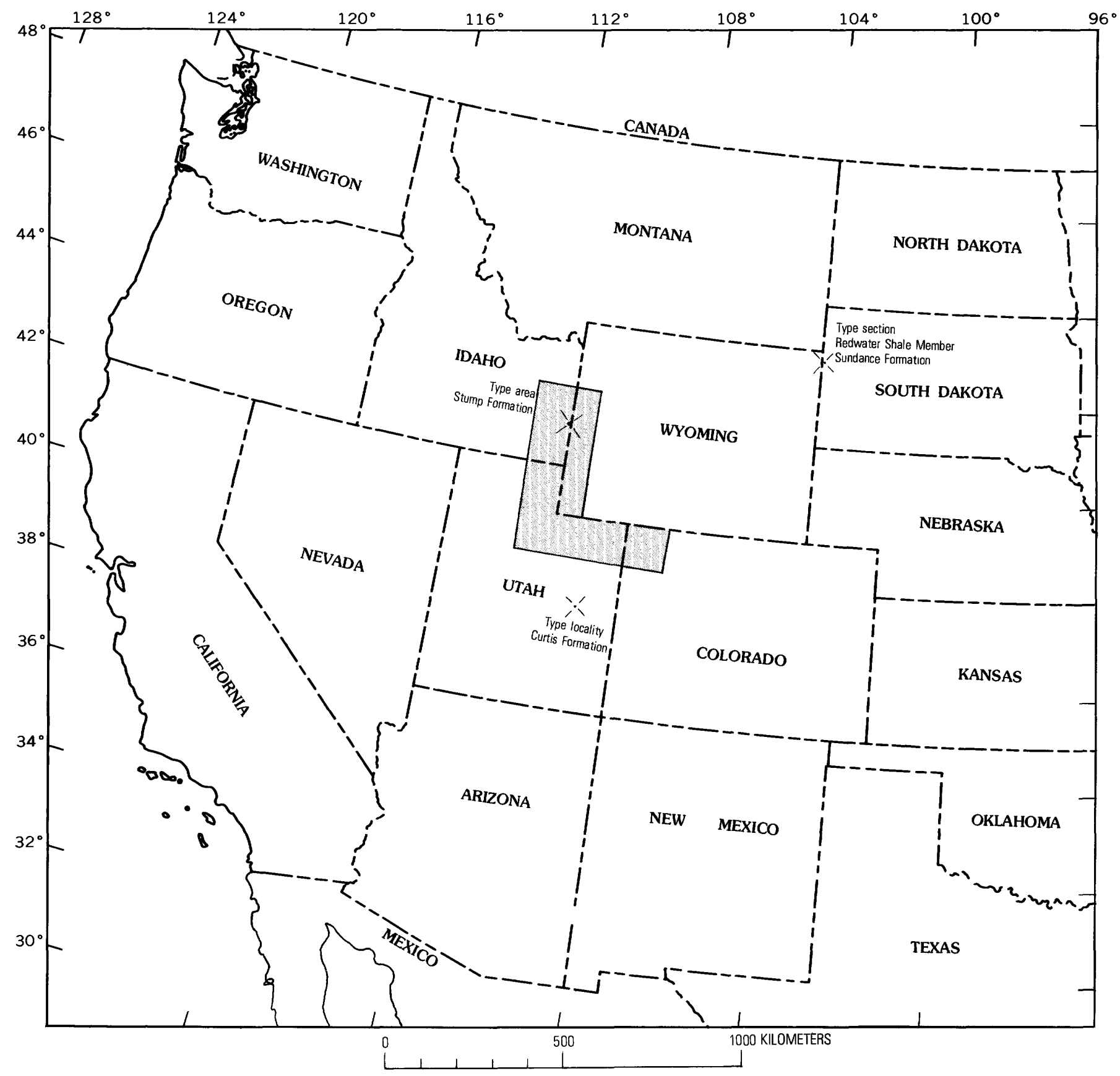

FIGURE I.-Distribution of Stump Formation (patterned) and location of type area, locality, and section, respectively, of Stump Formation, Curtis Formation, and Redwater Shale Member of Sundance Formation, Western United States.

overthrust belt. The formation ranges in thickness from $28 \mathrm{~m}$ to at least $120 \mathrm{~m}$ and thins from Idaho irregularly eastward and northward (table 1). Lithologically, the Stump Formation consists of a variety of marine sedimentary rocks that apparently change markedly within relatively short distances, as described by Mansfield and Roundy (1916, p. 76, 81); Mansfield (1927, p. 99-101; 1952, p. 38); Gardner (1944); Thomas and Krueger (1946, p. 1269, 1276, 1278, 1285);
Rubey (1958, 1973); Oriel (1963); Cressman (1964, p. 52, 53); Staatz and Albee (1963, 1966); Pampeyan and others (1967), Albee (1968); Schroeder (1969); and Rubey, Oriel, and Tracey $(1975$, p. 5$)$.

These irregular lateral variations in facies and thickness in the Stump Formation have hitherto been perplexing. In places the Stump resembles only the Curtis Formation of the San Rafael Swell in east-central Utah; in other places the 
Stump mainly resembles the Redwater Member of the Sundance Formation of Wyoming. Elsewhere, as in the western part of the Uinta Mountains, the Stump Formation, as used by Thomas and Krueger (1946, stratigraphic sections 1, 2, 3, p. 1276-1285), resembles both the typical Curtis Formation and the Redwater Member. It is now recognized (1) that the lower part of the Stump Formation throughout the Uinta Mountains is identical with the Curtis Formation of the San Rafael Swell and (2) that the upper part of the Stump is closely similar to the Redwater Member of the Sundance Formation farther to the north and to the east in Wyoming and northern Colorado (fig. 1). Furthermore, in the eastern part of the Uinta Mountains, the Curtis Formation, as used by Thomas and Krueger (1946, stratigraphic sections $4,5,6$, p. 1276, 1287-1290), is identical with the Stump of the western Uintas, and likewise includes two members of which only the lower is equivalent to the type Curtis Formation. It seems best, therefore, to extend the name Stump Formation to all of the Uinta Mountains.

Similarly, the Stump Formation along the ldahoWyoming border includes beds in its lower part that are nearly identical with the Curtis Formation, and it includes beds in its upper part that closely resemble the silty to sandy facies of the Redwater Member of the Sundance Formation. As these lithologic subdivisions are not very thick, the Stump is at present the practical unit for mapping purposes, and accordingly it is herein retained as a formation that is divided into the Curtis Member below and the Redwater Member above.

At most places, the Stump Formation rests with apparent conformity on reddish beds of the Preuss Sandstone. Locally, however, that contact is very sharp, as at Blacktail Canyon, Indian Camp Hollow (fig. 7), McCoy Creek (fig. 8), Shale Creek, and on old U.S. Highway 30 (abandoned) east of Evanston, Wyo. The contact is gradational within several centimeters at Telephone Hollow and La Barge Creek and is gradational within about a meter at Sheep Creek near Greys River. In some places, the contact is marked only by an upward color change from red to gray and may even show intertonguing as at Corral Creek (fig. 9) and Fish Creek. In other places, as at Indian Camp Hollow, McCoy Creek, and Shale Creek, the contact is marked also by a slightly irregular surface and by an abrupt upward change from fine-grained red sandstone to hard, thin-to medium-bedded gray sandstone. The regional characteristics of the Preuss Sandstone have been discussed by Mansfield (1927, p. 98, 99) and Imlay (1952, p. 1735, 1739).

The Stump Formation within the area of extensive thrust faulting in western Wyoming is overlain sharply and unconformably by continental beds of Early Cretaceous or locally younger ages (Mansfield, 1927, p. 101). In the Uinta Mountains the Stump is overlain by Upper Jurassic beds that have been assigned to the continental Morrison Formation and by unnamed Lower Cretaceous beds (Stokes, 1944, p. 969; 1955, p. 84; Hansen, 1965, p. 85, 86).

\section{CURTIS MEMBER}

The Curtis Member of the Stump Formation attains thicknesses of 76-113 m in the area between Stump Peak and Fish Creek but thins irregularly northward toward the Snake River, and it thins considerably eastward in western Wyoming to as little as $9 \mathrm{~m}$ in the Wyoming Range (table 1 ). Its lithologic and stratigraphic resemblance to the Curtis Formation of the San Rafael Swell shows that its equivalents extend considerably farther south in Utah than does the overlying Redwater Member whose southernmost exposures are in the Uinta Mountains.

The Curtis Member consists of two lithologic units, the lower dominantly sandstone and the upper chiefly clay shale. (See figs. 4 and 5.) The lower or sandstone unit is generally ledgy or cliff forming (figs. 7, 8,9), ranges in thickness from 6-77 $\mathrm{m}$, thins northward and eastward, and is characterized by glauconitic, thin- to thick-bedded sandstone interbedded with some sandy siltstone and silty shale. Most of the sandstone beds are fine to very fine grained, but some are medium grained and many are silty. Ripple marks are common and some low-angle crossbedding is present. Predominant colors are greenish gray to brownish gray, but locally some beds are red and resemble sandstone in the Preuss Sandstone (loc. 12, fig. 4; loc. 5, figs. 6, 9). Many bedding interfaces are characterized by tracks and furrowed trails, by round to flat shale pebble impressions, by a few cubical salt casts as large as $6 \mathrm{~mm}$, and locally by marine bivalves such Meleagrinella. Ostrea, and Camptonectes. At Watton Canyon (loc. 16, fig. 2) chert and shale pebbles and fragments of Pentacrinus are common. This also is true of conglomeratic beds near the base of the Curtis in the San Rafael Swell and in the Uinta Mountains.

The upper or shale unit of the Curtis Member varies considerably and irregularly in thickness from $35 \mathrm{~m}$ at Fish Creek (loc. 12, fig. 4) and possibly 73 m east of Evanston (loc. 17, fig. 6) to a feather edge from these places both eastward and southward (figs. 4, 5, 6). The unit thins northward slightly and eastward considerably from exposures on Stump Creek and Fish Creek. The unit forms the top part of the Stump Formation at Wolverine Canyon (section 1), Stump Peak (section 7), and Fish Creek (section 12), but is absent at places where the Redwater Member is thickest in the Wyoming Range, as at Telephone Creek section (section 9), Shale Creek (section 11), and La Barge Creek (section 14). It has an apparent thickness of 73 m east of Evanston (section 17), but in that section the beds are vertical, rest sharply on the red Preuss Sandstone instead of on the lower sandstone unit of the Curtis, and consist mostly of soft claystone that could easily be duplicated in part by folding or faulting. The lower $11 \mathrm{~m}$, containing some sandy beds at bottom and top, could conceivably be equivalent to the lower sandstone unit. Against such a possibility is the fact that a ledgy to cliff-forming sandstone is present at the base of the Stump Formation in every section along or near the Idaho-Wyoming border. 

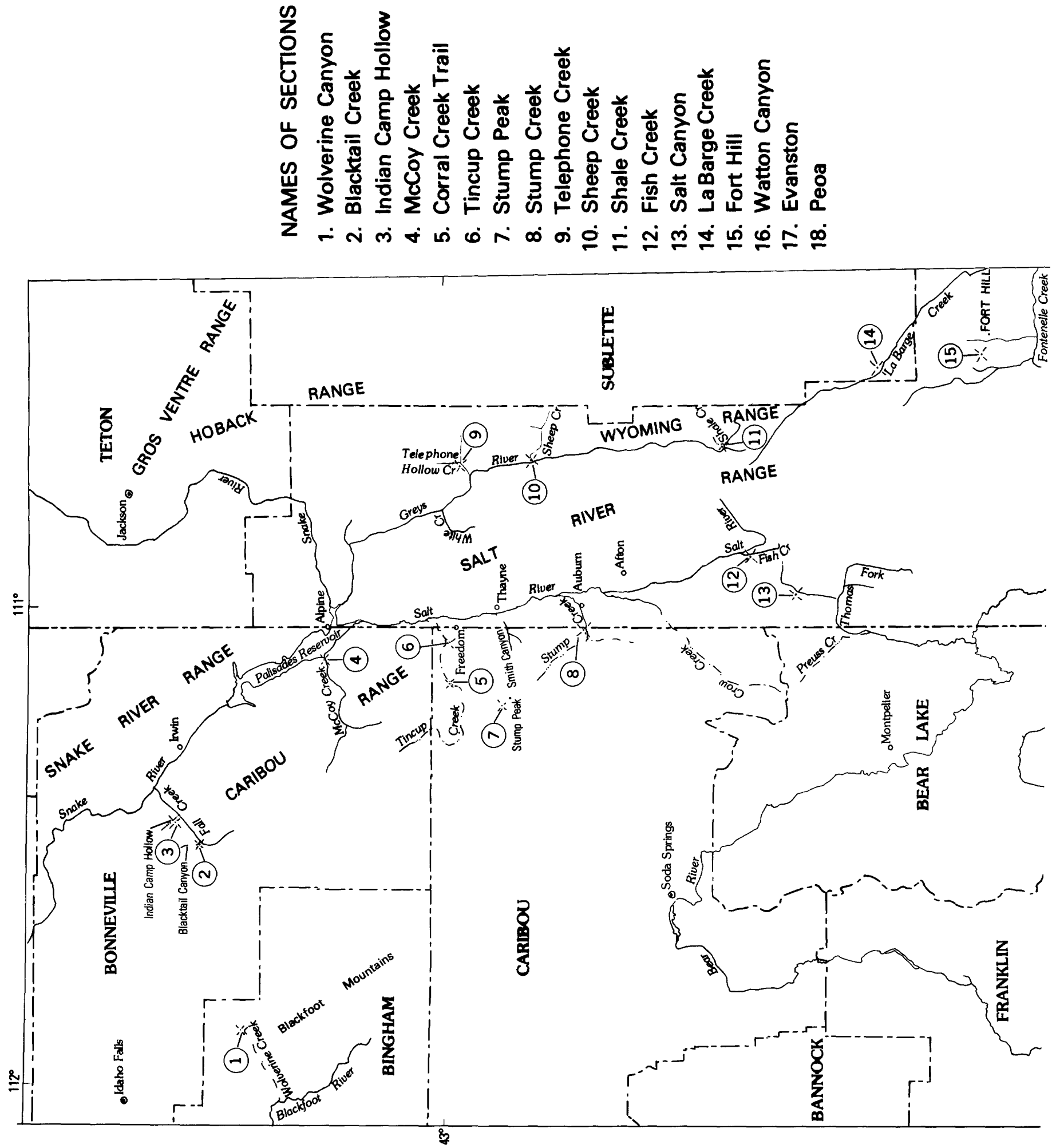


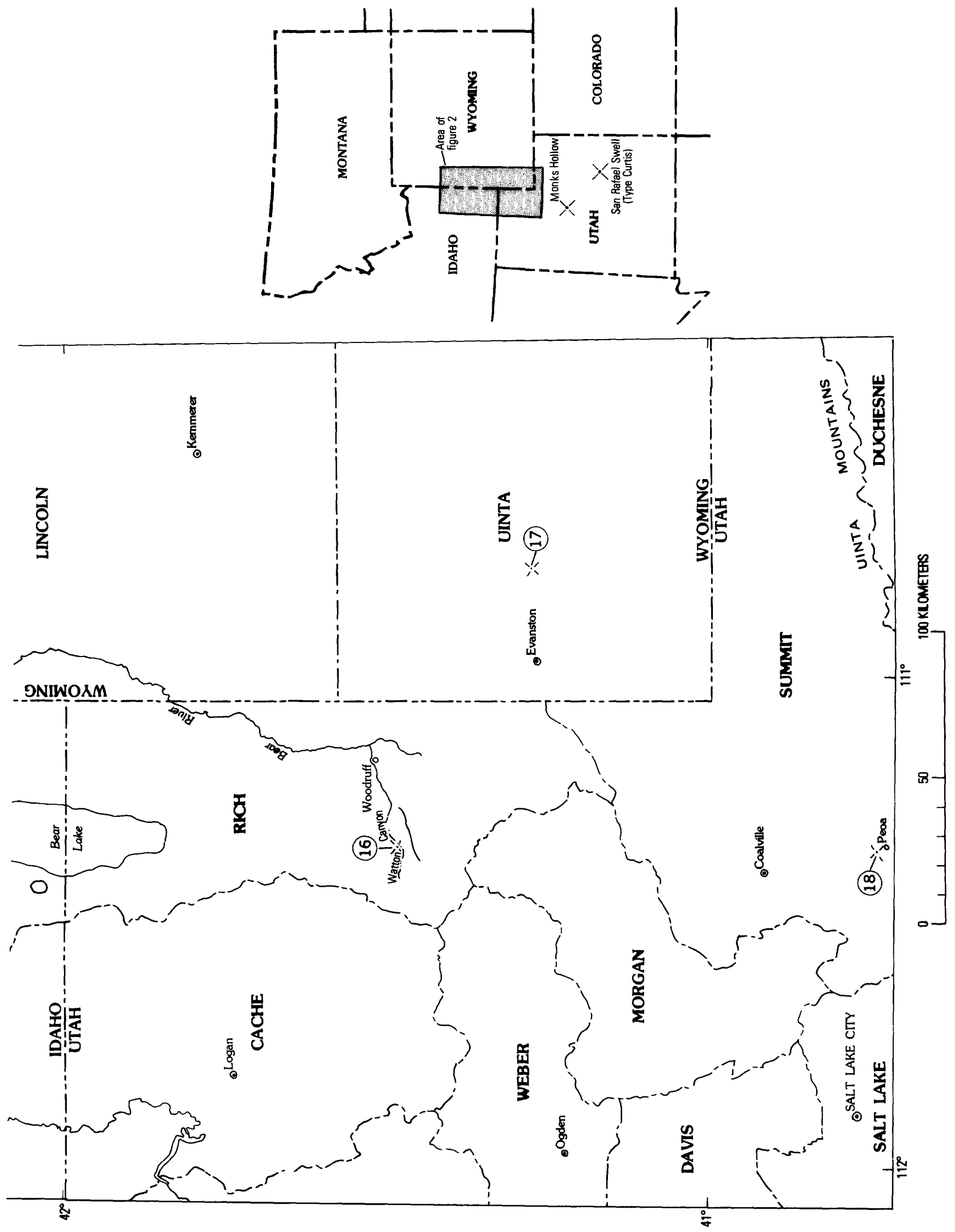




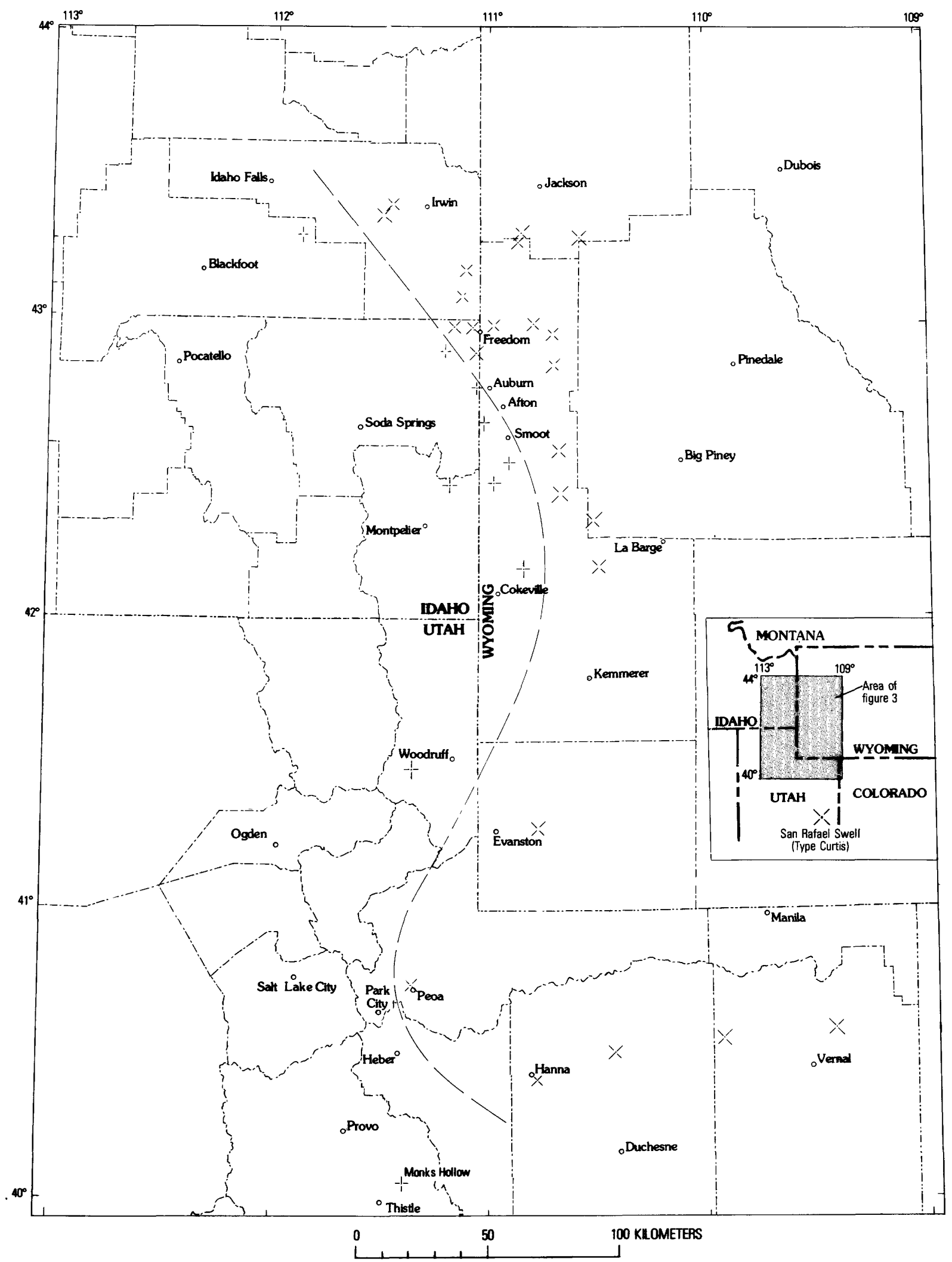

FIGURE 3.-Approximate margin of the Redwater Member of the Stump Formation (long-dashed line), southeastern Idaho and adjoining areas, based on lithology, unconformities, and occurrences of belemnites and ammonites. $X$, localities representing both Redwater and Curtis Members: +, localities representing only the Curtis Member. 


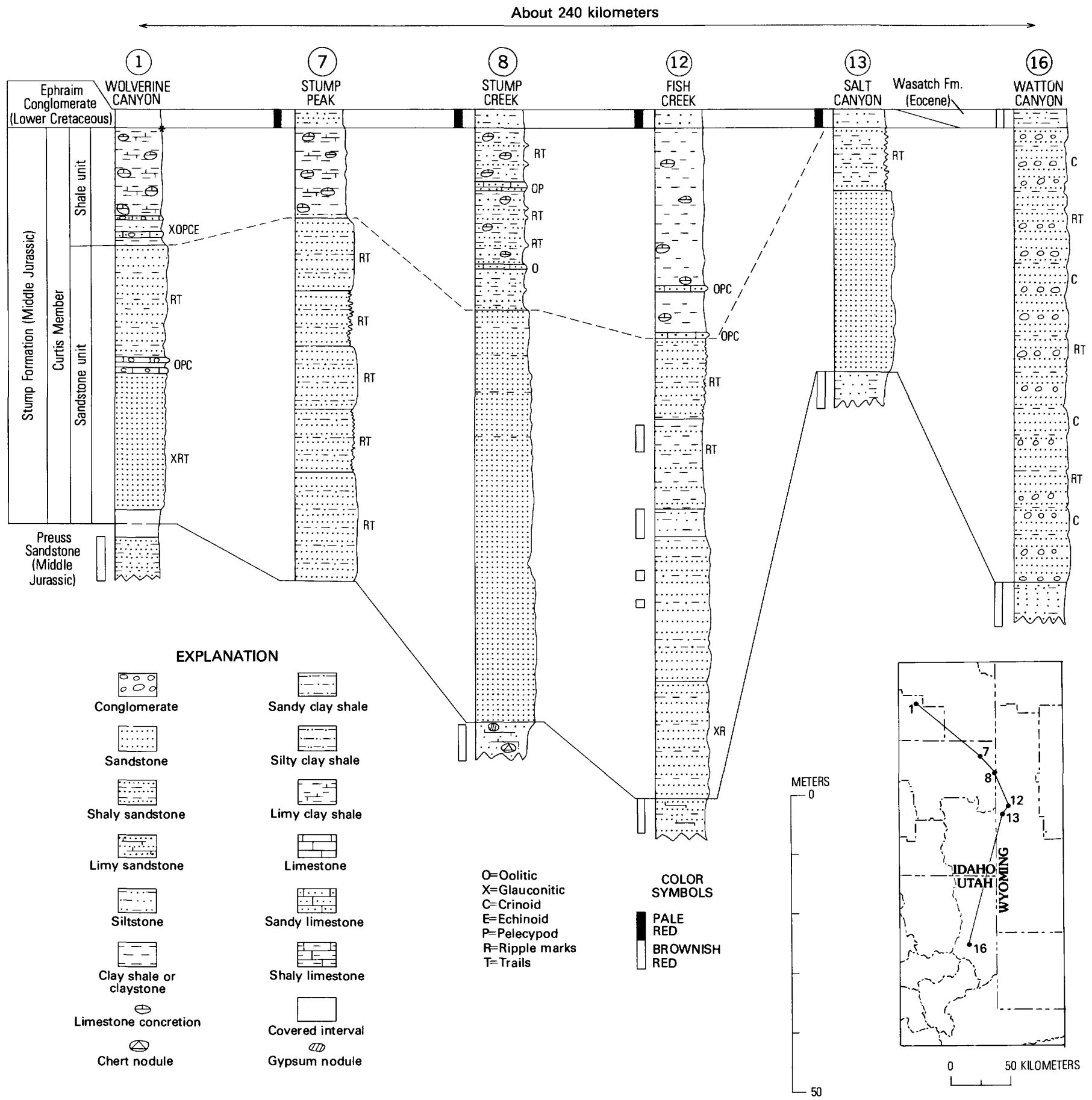

FIGURE 4.-Columnar sections of the Stump Formation from Wolverine Canyon, Idaho, to Watton Canyon, Utah. Unconformities are represented by solid lines and presumably conformable contacts by dashed lines. *, fault contact. (See description of bed 6 in Woiverine Canyon section.)

The shale unit of the Curtis Member consists mostly of limy, greenish-gray to olive-green, soft, flaky to fissile claystone that contains some very thin platy sandstone beds, some fossiliferous, oolitic limestone slabs, and many large, flat, lenticular yellowish-gray limestone concretions that weather nearly white. The limestone slabs contain oysters and crinoid stems, and the bedding surfaces of the thin sandstone beds bear tracks and trails. The base of the shale unit makes an abrupt but conformable contact with the underlying sandstone unit. 


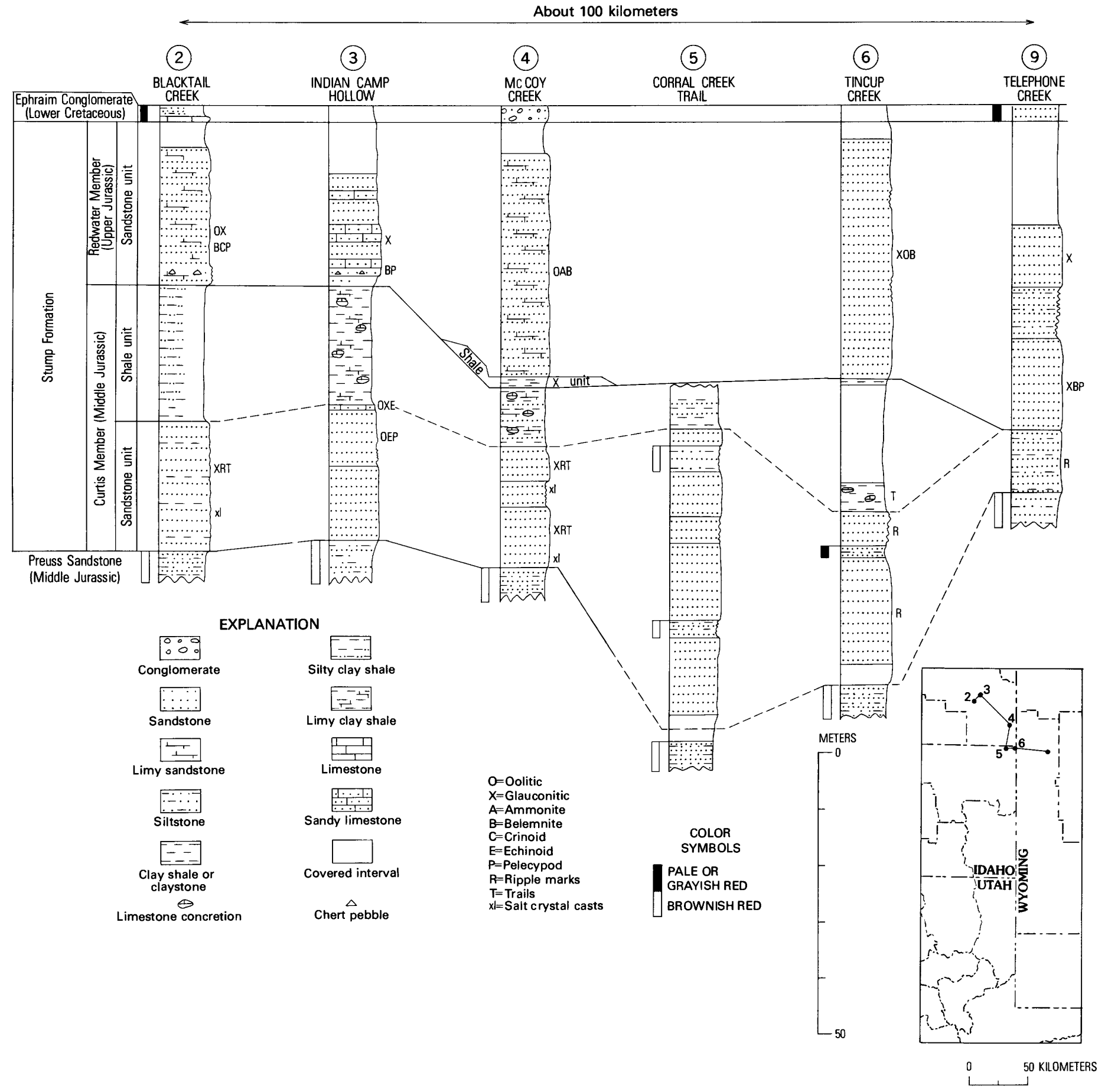

FIGURE 5.-Columnar sections of the Stump Formation from Blacktail Canyon, Idaho, to Telephone Hollow, Wyo. Unconformities are represented by solid lines and presumably conformable contacts by dashed lines.

The shale unit is correlated with part of the Curtis Formation of Utah because (1) it is conformable with the underlying sandstone unit but unconformable with the overlying Redwater; (2) nearly identical greenish-gray shale that contains light-gray limestone concretions occurs in the upper part of the Curtis Formation at Monks Hollow about $30 \mathrm{~km}$ southeast of Provo, Utah (Baker, 1947); and (3) similar greenish-gray flaky shale occurs in both the upper 


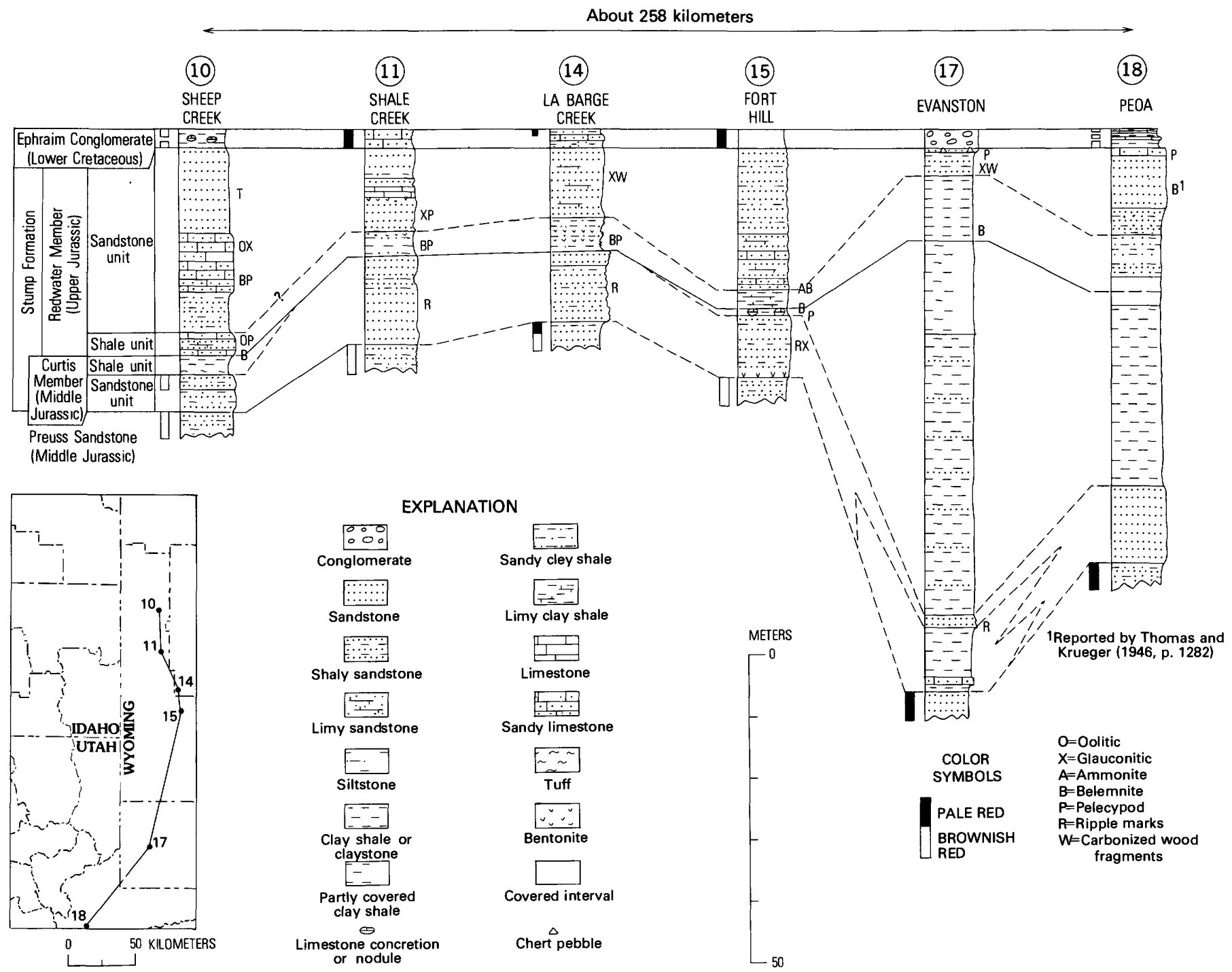

FIGURE 6.-Columnar sections of the Stump Formation from Sheep Creek, Wyo., to Peoa, Utah. Unconformities are represented by solid lines and presumably conformable contacts by dashed lines. Queried where correlation is in question.

and lower parts of the Curtis Formation at its type locality on the San Rafael Swell (Gilluly, 1929, p. 107, 108; Gilluly and Reeside, 1928, p. 79, 101).

The Curtis Member of the Stump Formation is assigned to the middle Callovian because (1) it unconformably underlies the Redwater Member of early to early middle Oxfordian age and (2) it overlies the Preuss Sandstone, which grades downward into beds of early Callovian age at the top of the Twin Creek Limestone.

\section{REDWATER MEMBER}

The Redwater Member of the Stump Formation is much less extensive than the Curtis Member. In southeastern Idaho the Redwater Member crops out north of the Snake River in the Snake River Range and in the southern part of the Teton Range. South of the Snake River in Idaho it crops out in the Caribou Range in a belt from 19 to $24 \mathrm{~km}$ wide that extends from the Fall Creek area southeastward toward Thayne, Wyo. Its southernmost occurrence is in the Caribou Range. Belemnites have been reported from the top of the Stump Formation about $4 \mathrm{~km}$ southwest of Thayne on Smith Canyon and $2 \mathrm{~km}$ west of the forest boundary in the SE $1 / 4$ sec. 10, T. 6 S., R. 46 E., Idaho (U.S. Geological Survey Mesozoic loc. 12120). This occurrence needs confirmation because the Stump Formation is not shown at that location by Mansfield (1927, pl. 5). In western Wyoming the Redwater Member is present in the mountains bordering Greys River as well as farther east in the Wyoming and Hoback Ranges, but it has not been recorded from the west side of the Salt River Range. 
TABLE 1.- Thicknesses of the Stump Formation and its subdivisions

[Thicknesses in meters, totals rounded; A, absent, queried where uncertain; C, covered; U, unknown]

\begin{tabular}{|c|c|c|c|c|c|c|c|c|}
\hline \multirow{2}{*}{\multicolumn{2}{|c|}{ Numbered localities }} & \multicolumn{3}{|c|}{ Redwater Member } & \multicolumn{3}{|c|}{ Curtis Member } & \multirow{2}{*}{$\begin{array}{c}\begin{array}{c}\text { Stump } \\
\text { Formation }\end{array} \\
\text { Total } \\
\text { thickness }\end{array}$} \\
\hline & & $\begin{array}{c}\text { Sandstone } \\
\text { unit }\end{array}$ & $\begin{array}{l}\text { Shale } \\
\text { unit }\end{array}$ & $\begin{array}{c}\text { Total } \\
\text { thickness }\end{array}$ & $\begin{array}{l}\text { Shale } \\
\text { unit }\end{array}$ & $\begin{array}{c}\text { Sandstone } \\
\text { unit }\end{array}$ & $\begin{array}{c}\text { Total } \\
\text { thickness }\end{array}$ & \\
\hline 1. & Wolverine Canyon---- & A & A & 0 & $19.8+$ & 44.2 & $64+$ & $64+$ \\
\hline 2 . & Blacktail Creek--.-- & 34 & $A$ & 34 & 24.4 & 22.8 & 47 & 81 \\
\hline 3. & Indian Camp Hollow-- & $18+$ & $A$ & $18+$ & 2.1 & 2.4 & 45 & $63+$ \\
\hline 4. & McCoy Creek----.--.- & 45.7 & 1.8 & 48 & 10.6 & 2.1 .3 & 32. & 79 \\
\hline 5. & Corral Creek Trail-- & $\mathrm{C}$ & $\mathrm{C}$ & $\mathrm{U}$ & $7.3+$ & 55.4 & $63+$ & $63+$ \\
\hline 6. & Tincup Creek-.--.-- & 45.4 & $\mathrm{~A}$ & 45 & 2.3 .6 & 31.1 & 55 & 100 \\
\hline 7. & Stump Peak--------- & $A$ & $A$ & 0 & 15.2 & 61 & 76 & 76 \\
\hline 8. & Stump Creek-------- & A & $A$ & 0 & 30.5 & 69.2 & 100 & 100 \\
\hline 9. & Telephone Creek----- & 54.5 & $A$ & 55 & A & 11.3 & 11 & 66 \\
\hline 10. & Sheep Creek--...... & 29.9 & 4 & 34 & 2.7 & 6.1 & 9 & 43 \\
\hline 11 . & Shale Creek-_- & 13.4 & 4 & 17 & $A$ & 14.3 & 14 & 32 \\
\hline 12 . & Fish Creek---.---- & A & $A$ & 0 & 35 & 77.7 & 113 & 113 \\
\hline 13. & Salt Canyon-------- & A & A & 0 & $A$ & 41.1 & 41 & 41 \\
\hline 14. & La Barge Creek--.--- & 11.3 & 5.6 & 17 & $A$ & 11.1 & 11 & 28 \\
\hline 15 . & Fort Hill--------- & 2.3 & 3 & 2.6 & 1 & 10 & 11 & 37 \\
\hline 16. & Watton Canyon-...... & A & $A$ & 0 & A & 76 & 76 & 76 \\
\hline 17. & Evanston--_-_- & 4.6 & 10.7 & 15 & 73.1 & A? & 73 & 88 \\
\hline 18. & Peoa-- & 14.3 & 11.3 & 25 & 29.3 & 12.5 & 42. & 67 \\
\hline
\end{tabular}

The Redwater Member ranges irregularly in thickness from about 15 to $55 \mathrm{~m}$. At some places its uppermost beds are covered, and total thicknesses cannot be determined; for instance, at Blacktail Canyon, Indian Camp Hollow, Tincup Creek, and west of Fort Hill. Nonetheless, the available data suggest that the Redwater Member thins southward along the Wyoming Range in western Wyoming.

Along the Idaho-Wyoming border and southward as far as Peoa, Utah, the Redwater Member consists of two lithologic units. The lower or shale unit is $2-11 \mathrm{~m}$ thick and consists of yellowish-gray to brown glauconitic chunky siltstone or claystone that is locally finely sandy and generally contains belemnites. Except for one occurrence at McCoy Creek (section 4) in Idaho, the lower shale unit has been definitely identified mainly on the flanks of the Wyoming Range in western Wyoming and in areas to the south near Evanston, Wyo., and Peoa, Utah. At Shale Creek (section 14) and La Barge Creek (section 15), the lower shale unit rests sharply on the sandstone unit of the Curtis Member and contains belemnites at its base, associated with many small, worn specimens of Gryphaea nebrascensis (Meek and Hayden). West of Fort Hill (section 16), the chunky lower shale unit of the Redwater Member contains belemnites but no gryphaeas and rests sharply on the flaky clay-shale unit of the Curtis Member.

In addition to occurrences of Grvphaea at Shale Creek and La Barge Creek, small, worn specimens of Gryphaea nebrascensis occur together with belemnites in the Stump
Formation at the following U.S. Geological Survey Mesozoic localities:

16024. Basal part of Redwater Member on creek of Telephone Hollow $2 \mathrm{~km}$ above mouth of Deadman Creek, Afton quadrangle, Wyoming.

16047. Unknown position in Redwater Member on White Creek $1 \mathrm{~km}$ upstream from bench mark 6758 and $91.4 \mathrm{~m}$ below waterfall SW. cor. NE $1 / 4$ sec. 30, T. 35 N., R. 117 W., Bedford quadrangle, Wyoming.

17897. Basal part of Redwater Member $1.2 \mathrm{~km}$ northwest of McCoy Creek, near center NW1/4 sec. 6, T. 3 S., R. 46 E., Alpine quadrangle, Idaho.

18183. From shale $9.1 \mathrm{~m}$ below top of Stump Formation near center of north line of NW1/4 sec. 25, T. 3S., R. $45 \mathrm{E}$., Poker Peak quadrangle, Idaho.

18185. From 36.6 to $61 \mathrm{~m}$ above base of Stump Formation, NW $1 / 4$ sec. 1, T. 4 S., R. 45 E., Tincup Mountain quadrangle, Idaho.

18187. From 61 to $71.6 \mathrm{~m}$ above base of Stump Formation, NE $1 / 4$ sec. 1, T. 4 S., R. 45 E., Irwin quadrangle, Idaho.

Fossils from Mesozoic fossil localities 16024 and 17897 include the ammonite Cardioceras and are definitely from the basal part of the Redwater Member. Those from locality 18185 are probably from the basal part of the Redwater Member if the members are similar in thickness to those at McCoy Creek about $9.6 \mathrm{~km}$ to the north. If so, the collection from locality 18187 was probably collected about $10.7 \mathrm{~m}$ 

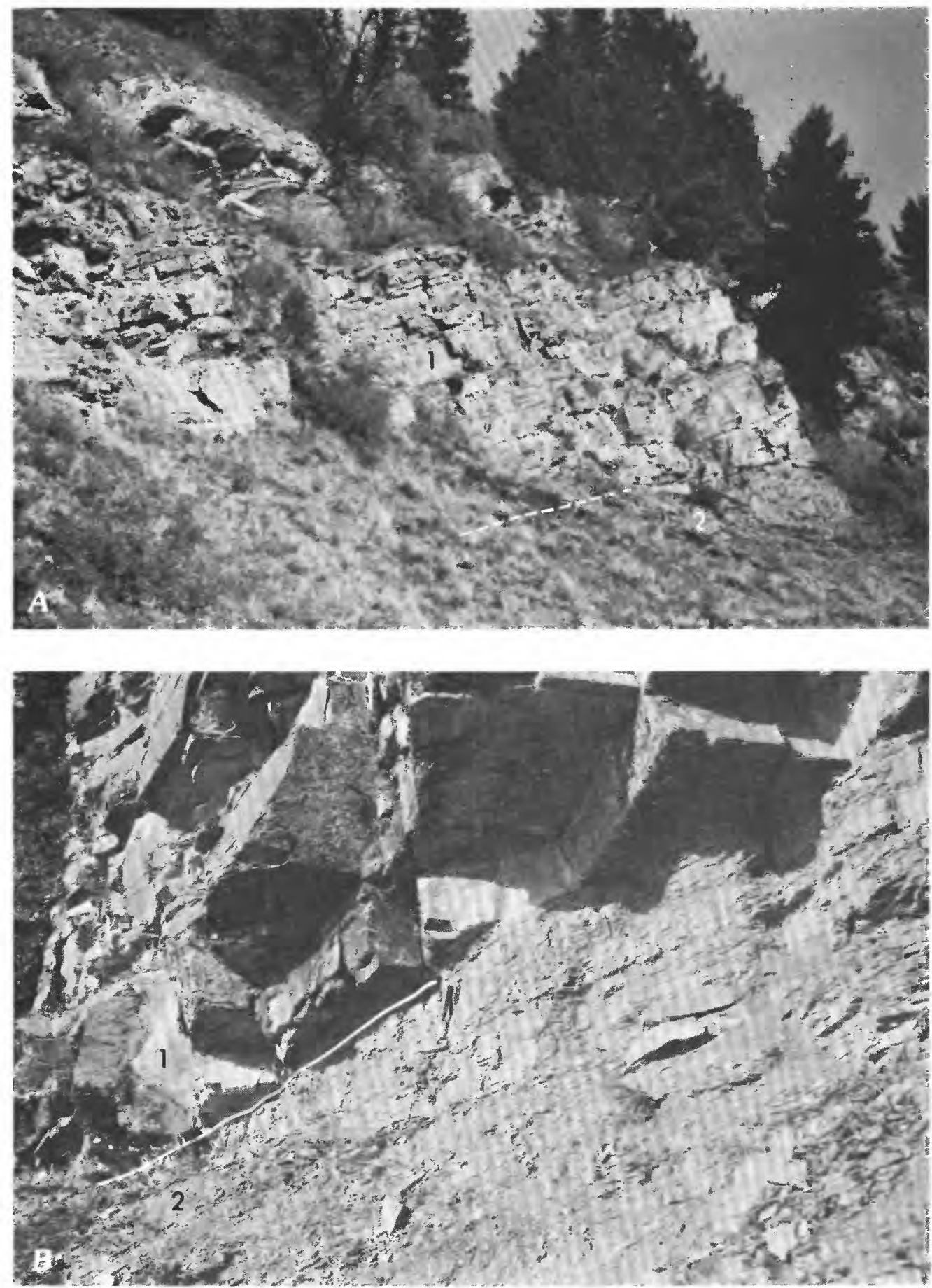

Figure 7.- Contact of the Stump Formation with the Preuss Sandstone at Indian Camp Hollow (loc. 3, fig. 5). A, thin-and medium-bedded ledgy cliff-forming appearance typical of the sandstone unit of the Curtis Member. Contact dashed where inferred. Lower cliff is about 12 $\mathrm{m}$ high. $B$, sharp, slightly channeling contact of the Stump with the Preuss. Hammer is about 28 centimeters long. In both views: 1 , Curtis Member, sandstone unit; 2; Preuss Sandstone.

above the base of the Redwater Member. Apparently only the fossils from locality 18183 were collected high in the formation, but the reported occurrence in shale at that position seems peculiar and needs confirmation. In addition, the fossils of Gryphaea nebrascensis in the Stump Formation of the Jackson quadrangle, Wyoming, as reported by Wanless, Belknap, and Foster (1955, p. 51, 52), are probably also in the basal or lower part of the Redwater Member 

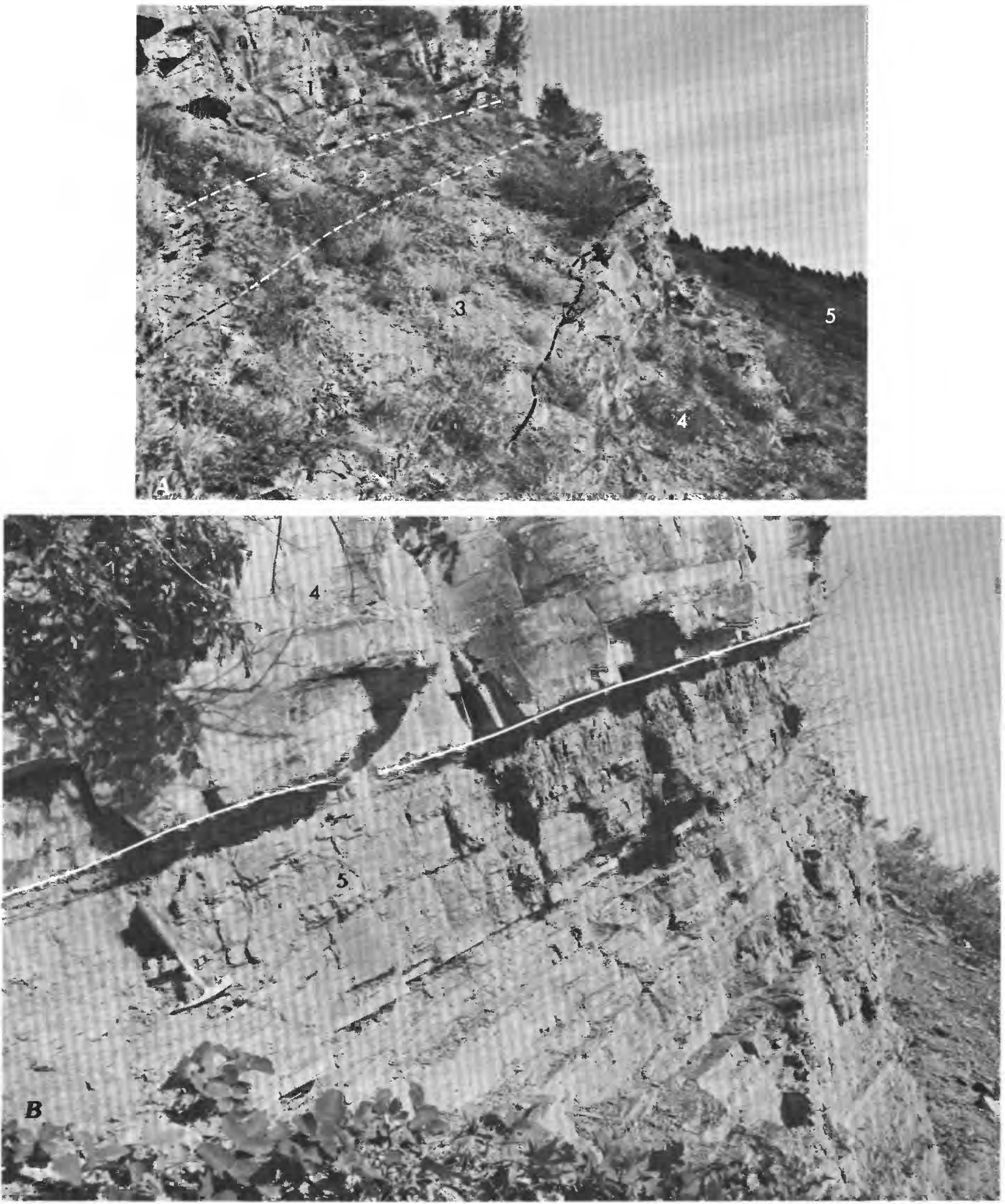

Figure 8.-Stump Formation at McCoy Creek (loc. 4, fig. 5). A, units: 1, Redwater Member, sandstone unit; 2, shale unit; 3, Curtis Member, shale unit; 4, sandstone unit; 5 , Preuss Sandstone. Lower cliff is about $10 \mathrm{~m}$ high. $B$, near view of contact between 4 , Curtis Member. sandstone unit, and 5, Preuss Sandstone. The contact shows relief of about $3 \mathrm{~cm}$. Hammer is about $28 \mathrm{~cm}$ long. 


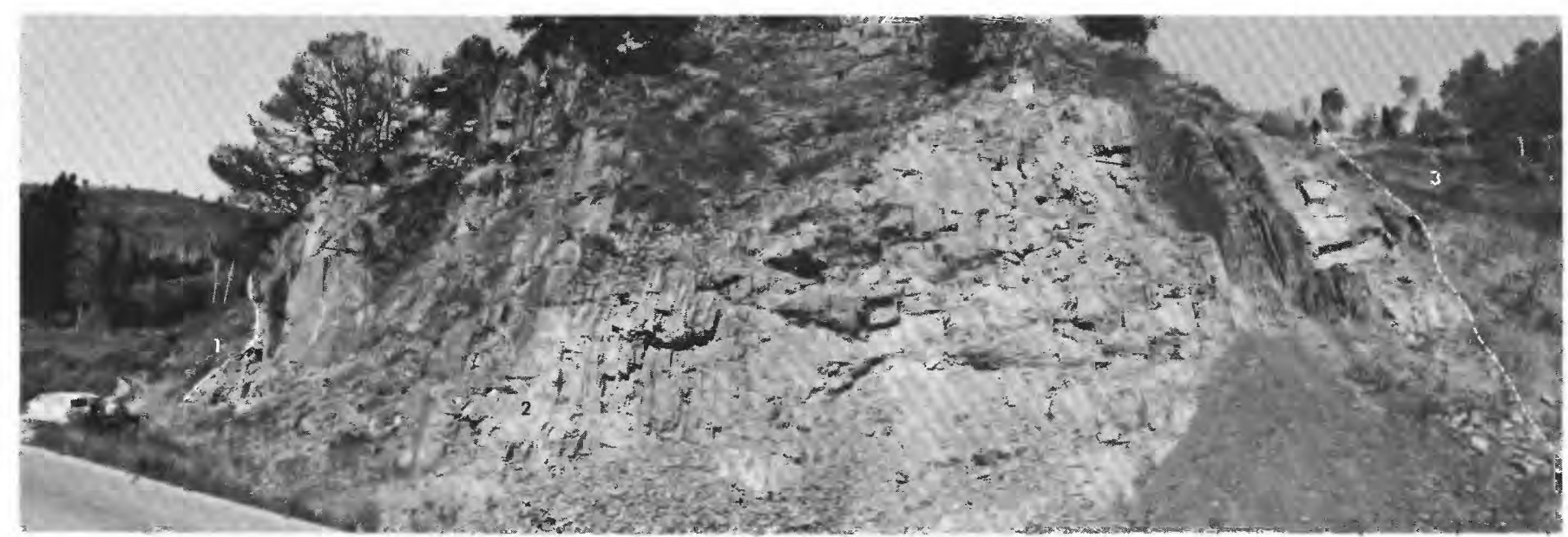

Figlre 9.- Sandstone unit of the Curtis Member at the start of Corral Creek trail (loc. 5, fig. 5; vehicle parked on trail). Arrow points to Preuss-like red beds within the Curtis Member suggesting local intertonguing with the Preuss. (1) Preuss Sandstone; (2) Curtis Member, sandstone unit; (3) Curtis Member, basal part of shale unit. Redwater Member is present on ridge to the right but not visible in photograph.

because they occur in gray limestone that underlies massive ridge-forming, green, glauconitic sandstone and overlies softer, greenish sandy shale and sandstone.

The worn appearance of these gryphaeas, their preservation mostly as parts of the umbonal area, their occurrence mainly at or near the base of the Redwater Member, and their absence in the underlying Curtis Member indicate that they were derived from the Leeds Creek Member of the Twin Creek Limestone, which contains many well-preserved, unworn, and much larger specimens of Gryphaea nebrascensis. Evidently they were derived from that member during an interval of erosion after deposition of the Curtis Member.

The upper or sandstone unit of the Redwater Member consists mostly of ledgy to cliff-forming sandstone that is thin to thick bedded, crossbedded, highly glauconitic, calcareous, gray to greenish gray or locally nearly white. Most sequences contain interbeds of sandy siltstone or soft, clayey siltstone partings. Sandy oolitic limestone beds are present locally. Chert pebbles are present in some sections in various parts of the member. Belemnites and bivalves are fairly common, and ammonites occur locally.

This unit differs from the cliff-forming sandstone unit at the base of the Curtis Member in that it has more fossils, contains ammonites and belemnites, has claystone and siltstone beds that weather chunky instead of flaky or fissile, contains few trace fossils, has glauconite grains that commonly are larger than associated sand grains instead of the same general size, and lacks clay-pebble imprints or small cubical-shaped casts or imprints of salt crystals.

The upper sandstone unit of the Redwater Member rests conformably on the lower chunky shale unit of the Redwater Member where present, or sharply on the shale unit or the sandstone unit of the Curtis Member. A disconformable relationship with the Curtis Member is indicated by the sharpness of the contact, by a marked lithologic change, and by the absence of the upper shale unit of the Curtis Member at some places (sections 12,14, and 15). The upper sandstone unit of the Redwater Member throughout most of the overthrust belt is overlain sharply and unconformably by red siltstone or conglomerates of the Lower Cretaceous Ephraim Conglomerate. In the Uinta Mountains it is overlain unconformably by the Upper Jurassic Morrison Formation.

The Redwater Member of the Stump Formation is correlated with the Redwater Shale Member of the Sundance Formation because it likewise contains belemnites in abundance from bottom to top, and it likewise contains Cardioceras. That genus occurs near the base of the member west of Fort Hill (section 16) and on the creek of Telephone Hollow (section 12), and in the lower part of the upper third of the member at McCoy Creek (section 4). The basal part of the Redwater Member on the creek of Telephone Hollow also contains Vaugonia quadrangularis (Hall and Whitfield) and Oxytoma wyomingensis (Stanton) along with Cardioceras and belemnites. In addition, the stratigraphically highest exposures of the member on McCoy Creek contain Oxytoma wyomingensis (Whitfield). The pelecypods occur in the Redwater Shale Member of the Sundance Formation as far east as the Black Hills and in the Middle and Upper Jurassic Swift Formation of Montana. The presence of Cardioceras shows that the Redwater Member of the Stump Formation is of early to early middle Oxfordian age.

\section{UNCONFORMITIES}

The lower contact of the Ephraim Conglomerate is an unconformity throughout the study area. The lower contact of the Redwater Member of the Stump is also an unconformity. The nature of the contact between the Curtis Member of the Stump and the Preuss Sandstone, however, is 



FIGURE 10.- Type area of the Stump Formation. A, southwestward view of an overturned but well-exposed section of the Stump Formation designated the principal reference section (loc. 7, fig. 4). A northwestward view of this locality was illustrated and described by Mansfield and Roundy (1916, p. 82, pl. 13a) as "a typical exposure of the Stump sandstone." 1, Curtis Member, sandstone unit; 2, Curtis Member. shale unit; 3, Ephraim Conglomerate. B, northeastward view of Stump Peak (arrow) on ridge held up by the sandstone unit of the Curtis Member. 1, Ephraim Conglomerate; 2, Curtis Member, sandstone unit; 3, Preuss Sandstone; 4, Twin Creek Limestone undivided, consisting principally of the Leeds Creek Member. North Fork of Stump Creek is in lower right of photograph. Contacts dashed where inferred. 


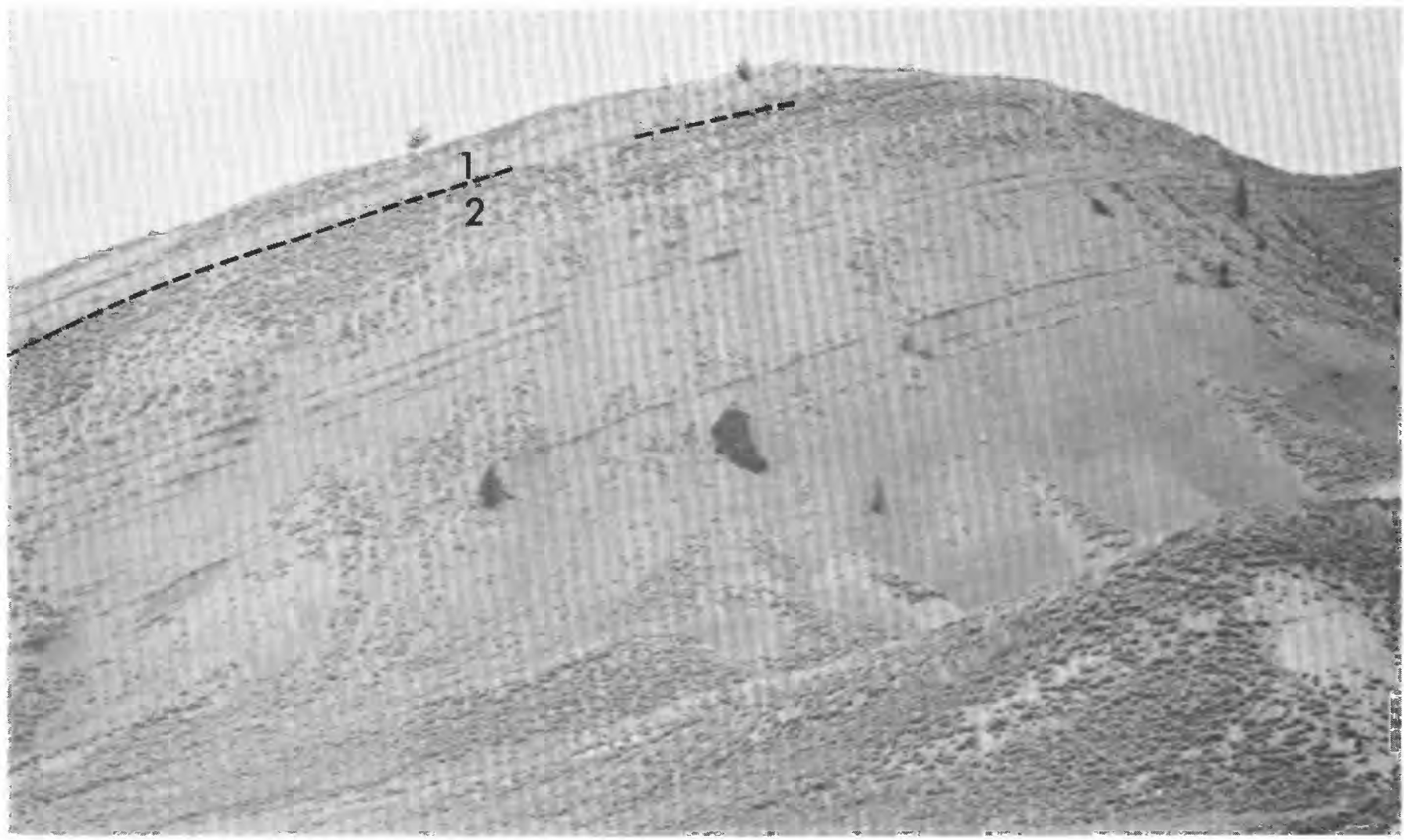

Figure 11.--Contact of the Stump Formation with the Preuss Sandstone at Stump Creek (loc. 8. fig. 4). 1, Stump Formation, sandstone unit; 2, Preuss Sandstone.

uncertain. The contact is sharp and probably unconformable at localities $2,3,4,8,11,16$, and 17 ; it is concealed at localities $1,6,7$, and 18 ; it is conformable at localities 9,13 , 14, and 15; and perhaps the Curtis Member and Preuss intertongue at localities 5, 10, and 12 .

Marked differences in lithologic characteristics, fossils, and thicknesses occur within relatively short distances in the Stump Formation as now mapped. These differences are attributable primarily to truncation of units beneath the unconformities at the base of the Ephraim Conglomerate and at the base of the Redwater Member of the Stump Formation. (See figs. 4, 5, and 6.)

The unconformities at the base of the Ephraim, at the base of the Redwater, and at the base of the Curtis, where present, have been designated the $\mathrm{K}, \mathrm{J}-4$, and $\mathbf{J}-3$ unconformities, respectively, by Pipiringos and O'Sullivan (1978).

The unconformity at the base of the Ephraim Conglomerate probably represents at least part of the late Tithonian; the one at the base of the Redwater Member represents most of the late Callovian; and the unconformity that is at least locally present at the base of the Curtis Member may represent a small part of the middle Callovian. The latest time represented by the unconformity at the base of the Redwater Member is dated accurately by the presence of ammonites of early Oxfordian age in the lower part of that member.

\section{STRATIGRAPHIC SECTIONS}

The Stump Formation was named after a sandstone sequence on Stump Peak in the Freedom quadrangle, Idaho, by Mansfield and Roundy (1916, p. 76, 81), who did not designate a type section. That sandstone forms a ridge that extends southeastward for $5 \mathrm{~km}$ through the peak. Near the northwest end of the ridge, an overturned sequence (loc. 7) is well exposed (fig. 10A). Approximately $1.6 \mathrm{~km}$ to the southeast at Stump Peak (NE1/4 NW1/4 sec. 16, T. 6 S., R. 45 E.), the sequence of beds in the Stump Formation is the same and is in normal superposition, but it is less well exposed. About $2 \mathrm{~km}$ farther southeast, in the $\mathrm{SE}^{1} / 4 \mathrm{NW}^{1} 1 / 4 \mathrm{sec}$. 22, outcrops are even poorer, and, in addition, much of the upper part of the Stump Formation is missing owing either to erosion or to faulting (fig. 10B). The sequence near the northwest end of the ridge (loc. 7) is the best exposed and the most accessible within the type area. Furthermore, locality 7 was illustrated by Mansfield and Roundy (1916, pl. 13A), who stated that it shows a typical exposure of the Stump Formation. For these reasons, it is here selected as the principal reference section for the Stump Formation.

In addition, lithologically similar and better exposed reference sections also designated in this report that are readily accessible by car are to the southeast at Stump Creek (section 8), Crow Creek, and Fish Creek (section 12). The 


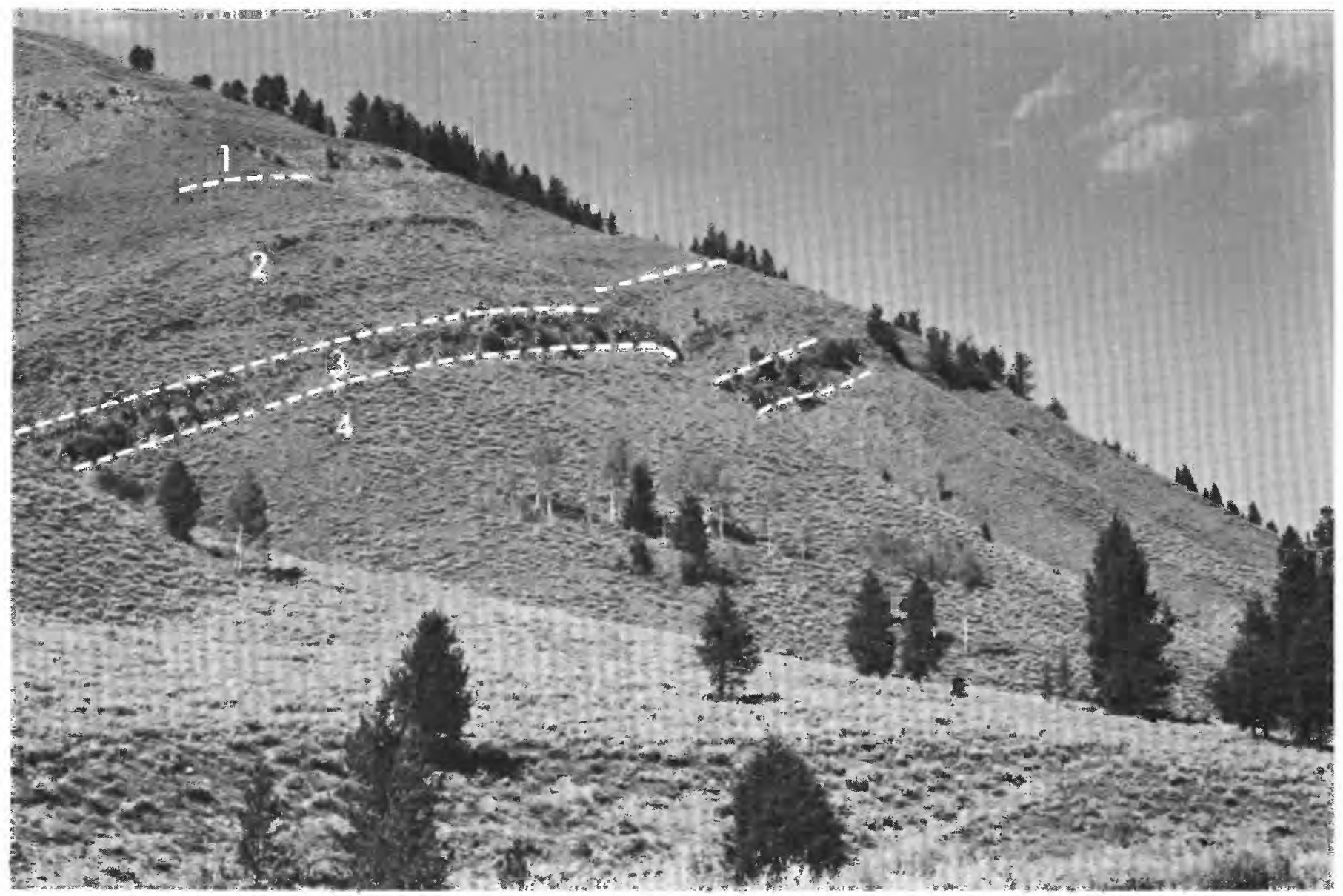

Figure 12.--Ephraim Conglomerate, Stump Formation, and Preuss Sandstone at Telephone Creek section (loc. 9, fig. 5). 1, Ephraim Conglomerate; 2, Redwater Member, sandstone unit; 3, Curtis Member, sandstone unit; 4, Preuss Sandstone.

section on the north side of Crow Creek ( $\mathrm{SE}^{1 / 4} \mathrm{NW} 1 / 4 \mathrm{sec} .17$, T. 31 N., R. 119 W., Crow Creek quadrangle, Lincoln County, Wyo.) differs from that on Stump Creek by the presence of thin beds of oolitic limestone that contain crinoid columnals and the pelecypod Camptonectes. Such limestone beds occur within a claystone unit at the very top of the formation as well as $18.2-21.3 \mathrm{~m}$ lower.

All these sections from Stump Peak southward along the Idaho-Wyoming border, as well as at Watton Canyon, Utah, are represented only by lithologies closely similar to those in the Curtis Formation of northern Utah, and they do not contain any units that are lithologically or faunally comparable with the Redwater Member of the Sundance Formation.

Well-exposed and easily accessible sections for the Redwater Member of the Stump Formation are at McCoy Creek (section 4), Telephone Creek (section 9), Sheep Creek (section 10), Shale Creek (section 11), and La Barge Creek (section 14).
In the descriptions that follow, the crossbedding noted in the sandstone beds of the Redwater Member seems to be of the medium-angle, trough cross-stratified type, occurring in sets $0.5-2 \mathrm{~m}$ thick. The crossbedding in the sandstone beds of the Curtis Member is exclusively low angle, trough cross stratified in sets $3-10 \mathrm{~cm}$ thick. In general the Redwater Member was deposited by currents of lower velocities than the currents that deposited the Curtis Member.

Indications of the position of unconformities in the stratigraphic descriptions have been omitted in order to shorten the descriptions; for the most part insertion of the word unconformity is repetitive and unnecessary. In figures 4,5 , and 6 , the unconformities are shown by solid lines and conformable contacts by dashed lines.

For similar reasons the thicknesses of individual stratigraphic units are omitted in figures 4 and 6 but are summarized in table 1. Formation and member thicknesses in text and in table 1, originally measured in feet, were converted to meters and rounded. 


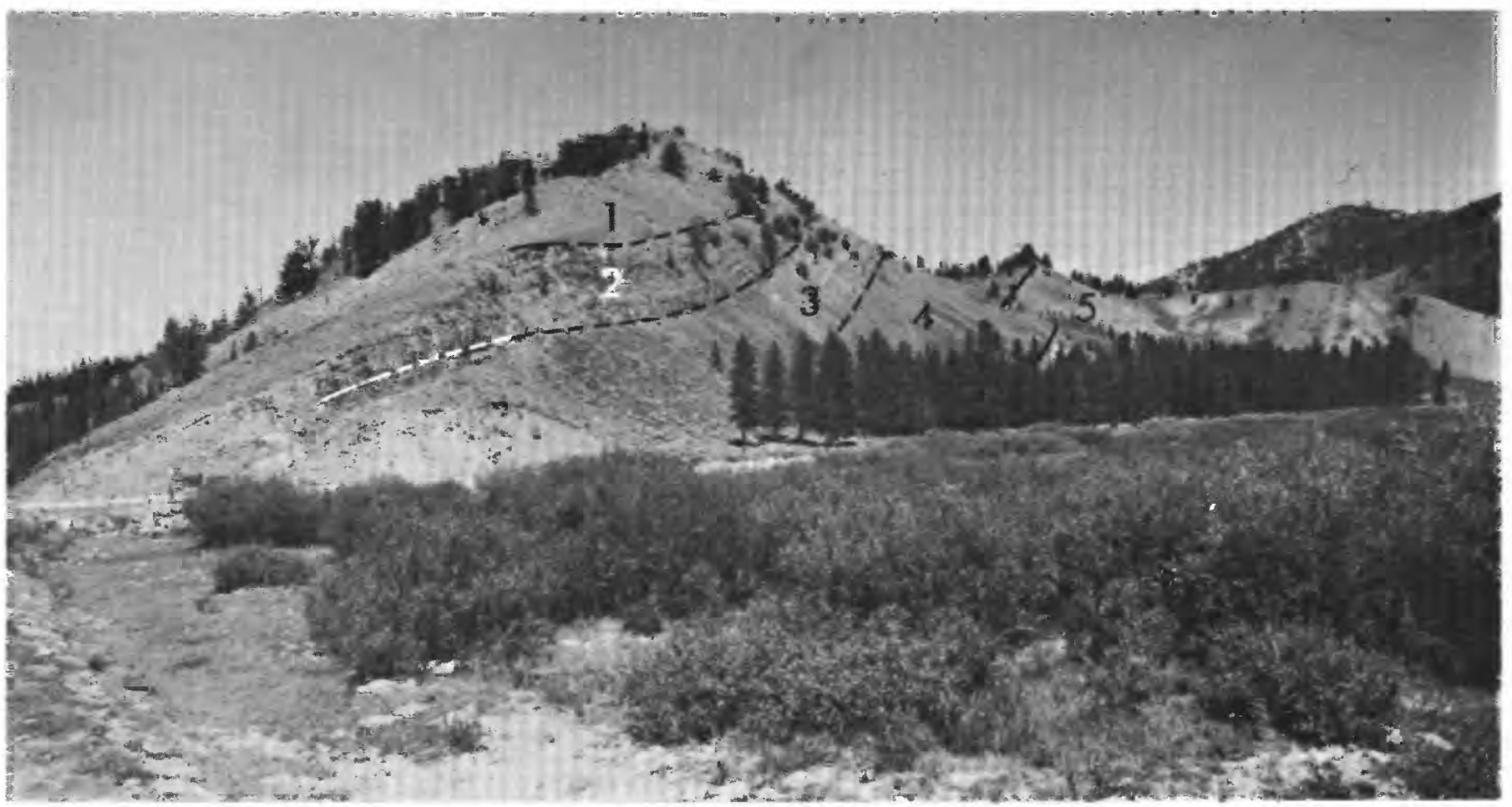

FIGURE 13.-Ephraim Conglomerate, Stump Formation, Preuss Sandstone, and Twin Creek Limestone near junction of Sheep Creek with Greys River (loc. 10, fig. 6). 1, Ephraim Conglomerate; 2, Redwater Member, sandstone unit; 3, Curtis Member, shale and sandstone units undivided; 4, Preuss Sandstone; 5, Twin Creek Limestone undivided.

Section 1.-Wolverine Canyon

[Stump Formation on north side of Wolverine Canyon in $\mathrm{E}^{1 / 2} \mathrm{NE}^{1 / 4} \mathrm{NE}^{1 / 4}$ sec. 28. T. $1 \mathrm{~S}$., R. $39 \mathrm{E}$. Ammon quadrangle. Bingham County, Idaho]

Ephraim Conglomerate (incomplete):

6. Mostly covered; base concealed; soil is grayish red; reported by Mansfield (1952, p. 63, pl. 1) to be in fault contact with underlying Stump Formation

Stump Formation

Curtis Member (incomplete):

Shale unit (incomplete):

5. Clay shale, limy, gray; contains lenticular flattened limestone concretions .....................................15.2+

4. Oolite slabs and thin limy siltstone and shale beds, sandy, gray, glauconitic; contains oysters, crinoid stems, echinoid spines, Camptonectes interbedded with some gray shale; unit makes slope

Sandstone unit:

3. Sandstone, very fine grained, flaggy, mostly gray, ripple-marked; bears many tracks and trails; contains many layers of olive-gray clay shale; basal meter contains slabs of oolite that bear crinoid columnals and oyster fragments .......... 21.3

2. Sandstone, ledgy to cliff-forming, thin- to medium-bedded, medium- to fine-grained, brownish-gray, glauconitic: some low-angle crossbedding, ripple-marked, some tracks and trails present; a thin oolite bed at top contains
Section 1.-Wolverine Canyon-Continued

Thickness (meters)

Stump Formation-Continued

Curtis Member (incomplete)-Continued

Sandstone unit-Continued

crinoid columnals and oyster fragments, base of unit concealed

Partial thickness of Stump Formation ..... 64t

1. Covered interval, probably partly Preuss

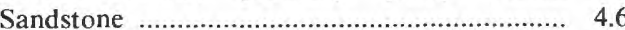

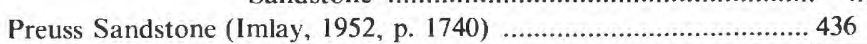

\section{Section 2.-Blacktail Creek}

[Stump Formation on west side of Fall Creek just south of Blacktail Canyon in NE1/4 sec. 34, T, $1 \mathrm{~N}$., R. 42 E. Conant Valley and Commissary Ridge quadrangles, Bonneville County, ldahol Ephraim Conglomerate (incomplete):

5. Partly covered pale-red sandy siltstone with a bed of light-gray limestone at the base; basal contact concealed makes slope; limestone makes ledge $9+$

Stump Formation:

Redwater Member:

Sandstone unit:

4. Mostly covered. Some siltstone and silty sandstone, ripple-marked, gray, base not exposed

3. Sandstone, thin- to medium-bedded, crossbedded, glauconitic, ledgy at base, some shaly beds, some 


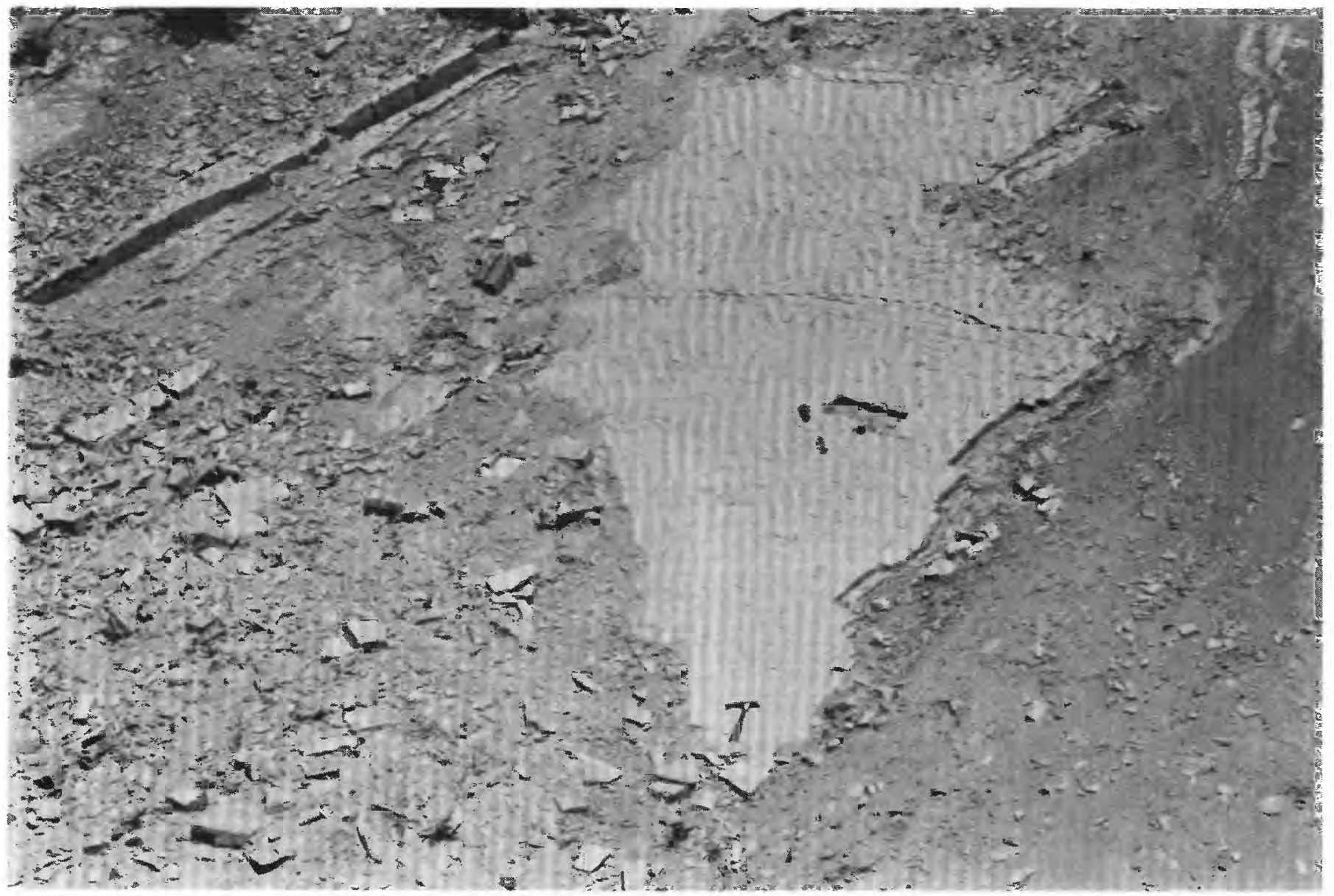

FIGURE 14.-Bedding features typical of the Curtis Member, sandstone unit of the Stump Formation. Exposure is on east side of U.S. Highway 89 about $400 \mathrm{~m}$ south of the Fish Creek stratigraphic section (loc. 12, fig. 4). Hammer is about $28 \mathrm{~cm}$ long.

Section 2.-Blacktail Creek-Continued

$$
\text { Thickness }
$$

(meters)

Stump Formation-Continued

Redwater Member-Continued

Sandstone unit-Continued

oolitic beds, brownish-gray; contains belemnites, oysters, crinoid fragments, and some small cher pebbles

Thickness of Redwater Member $\frac{24.4}{34}$

Curtis Member:

Shale unit:

2. Mostly covered clay shale, silty, medium-gray; contains thin oolitic limestone beds near base, just above a bed of olive-green clay shale about 1 meter thick that rests sharply on underlying unit; uppermost meter may belong to Redwater Member

Sandstone unit:

1. Sandstone, thick- to thin-bedded, ledgy; some platy shale; glauconitic, ripple marked, slightly crossbedded; bears trails and some cubical salt
Section 2.-Blacktail Creek-Continued

Thickness

(meters)

Stump Formation-Continued

Curtis Member-Continued

Sandstone unit-Continued

crystal casts. Rests fairly sharply on the underlying red siltstone

22.8

Thickness of Curtis Member

Preuss Sandstone (Imlay, this report)

\section{Section 3.-Indian Camp Hollow}

[Stump Formation on ridge south of Indian Camp Hollow, about $1.6 \mathrm{~km}$ west of Fall Creek in SE1/4 sec. 13, T. I N., R. 42 E., Conant Valley quadrangle, Bonneville County, Idaho. See figure 7] Ephraim Conglomerate (covered).

Stump Formation (incomplete):

Redwater Member (incomplete):

Sandstone unit (incomplete):

3. Sandstone and sandy limestone, medium- to thin-bedded, speckled, highly glauconitic, 
Section 3.-Indian Camp Hollow-Continued

Stump Formation (incomplete) - Continued

Redwater Member (incomplete)—Continued

Sandstone unit (incomplete)-Continued

grayish-yellow, forms low ledge. Basal $4 \mathrm{~m}$ contains some chert pebbles, belemnites, Pinna, Gervillia, Camptonectes, and many oysters. Exact contact with underlying shale not observed. Estimated exposed thickness

Curtis Member:

Shale unit:

2. Clay shale, calcareous, soft, gray, flaky, contains some large, flat, yellowish-white limestone concretions 21

Sandstone unit:

1. Sandstone, cliff-forming, gray, mostly thick bedded to massive, some thin-bedded sandstone in middle fourth, upper $9 \mathrm{~m}$ is oolitic and contains many oysters and echinoid spines. Upper contact with clay shale is sharp and has a relief of about $7 \mathrm{~cm}$. Lower contact with red shaly siltstone at top of Preuss Sandstone is very sharp

Thickness of Curtis Member ... 24

Partial thickness of Stump Formation

Preuss Sandstone (Vine, 1959, p. 260)

\section{Section 4.-McCoy Creek}

[Stump Formation on north side of McCoy Creek near center of $\mathrm{E}^{1} / 2 \mathrm{SW} 1 / 4$ sec. 6, T. 3 S., R. $46 \mathrm{E}$ Alpine quadrangle, Bonneville County, Idaho. See figure 8]

Ephraim Conglomerate (incomplete):

8. Conglomerate, gray, clasts mostly black and white chert

Stump Formation:

Redwater Member:

Sandstone unit:

7. Sandstone, gray, fine-grained, calcareous, oolitic, mostly thick bedded, ledgy; approximately the upper 5 is covered. Ammonites and belemnites found about $10 \mathrm{~m}$ below the highest exposure of the sandstone unit about $15 \mathrm{~m}$ below the lowest exposure of the Ephraim Conglomerate

Shale unit:

6. Siltstone, clayey, chunky, gray, glauconitic; upper $1.2 \mathrm{~m}$ well exposed; contact with Curtis Member is covered

Thickness of Redwater Member

Curtis Member:

Shale unit:

5. Clay shale, calcareous, soft, flaky to fissile, containing large, flat, yellowish-white limestone concretions and some thin, platy sandstone beds; top $0.6 \mathrm{~m}$ covered

Sandstone unit:

4. Sandstone, greenish-gray to brownish-gray, fine-grained, glauconitic, ripple-marked, thin- to medium-bedded; contains trails and salt-crystal casts; cliff forming

3. Sandstone, shaly, glauconitic, forms recess in cliff 4.6
Section 4.-McCoy Creek-Continued

Thickness

(meters)

Stump Formation Continued

Redwater Member-Continued

Sandstone unit - Continued

2. Sandstone as at top of unit, basal contact very sharp, shows local relief of about $3 \mathrm{~cm}$........... 10.7

Thickness of Curtis Member ...................

Preuss Sandstone (incomplete):

I. Sandstone, thin-bedded, very fine grained, grayish-red and calcareous

Section 5.- Corral Creek Trail

[Stump Formation at heginning of Corral Creek trail on north side of Tincup Creek in SE corner sec. 10. T. 5 S., R. 45 E., Freedom quadrangle. Caribou County, Idaho. See figure 9]

Ephraim Conglomerate (not examined).

Stump Formation (incomplete):

Redwater Member (not exposed near road).

Curtis Member (incomplete):

Shale unit (incomplete):

9. Shale, fissile, soft, gray; contains a few thin beds of sandstone

Sandstone unit:

8. Sandstone, thick-bedded, gray …........................ 3.0

7. Siltstone and sandstone, reddish-brown .............. 4.6

6. Sandstone. thick- to medium-bedded, gray ......... 8.2

5. Sandstone, thin-bedded, gray ............................. 4.6

4. Sandstone, thick- to medium-bedded, gray ......... 13.7

3. Siltstone and sandstone, thin-bedded, dullbrownish-red ................................................. 3.0

2. Sandstone, thick- to medium-bedded, gray ......... 13.7

1. Covered ............................................................ 4.6

Partial thickness of Stump Formation ..63+

Preuss Sandstone (not examined).

\section{Section 6.-Tincup Creek}

[Stump Formation on Tincup Creek on south side of Idaho Highway 34, about $3.2 \mathrm{~km}$ northwest of Freedom in NE $1 / 2$ SW1/4 sec. 9, T. 5 S., R. 46 E., Freedom quadrangle. Catibou County, Idaho (Manstield. 1927, pl. 5)]

Ephraim Conglomerate (base concealed).

Stump Formation:

Redwater Member:

Sandstone unit:

7. Sandstone, thick- to thin-bedded, glauconitic, gray; some oolitic beds; contains some belemnites near middle; uppermost part is covered

Curtis Member:

Shale unit:

6. Shale, olive-green, flaky to fissile ........................ 1.2

5. Covered (probably underlain by soft shale) ......... 17.4

4. Shale, finely fissile to platy, olive-green; weathers yellowish; bears tracks and trails; contains medium-gray limestone concretions ................ 5

Sandstone unit:

3. Sandstone, medium- to thin-bedded, gray, ripple-marked

2. Siltstone and sandstone, red to gray, resembles Preuss Sandstone 


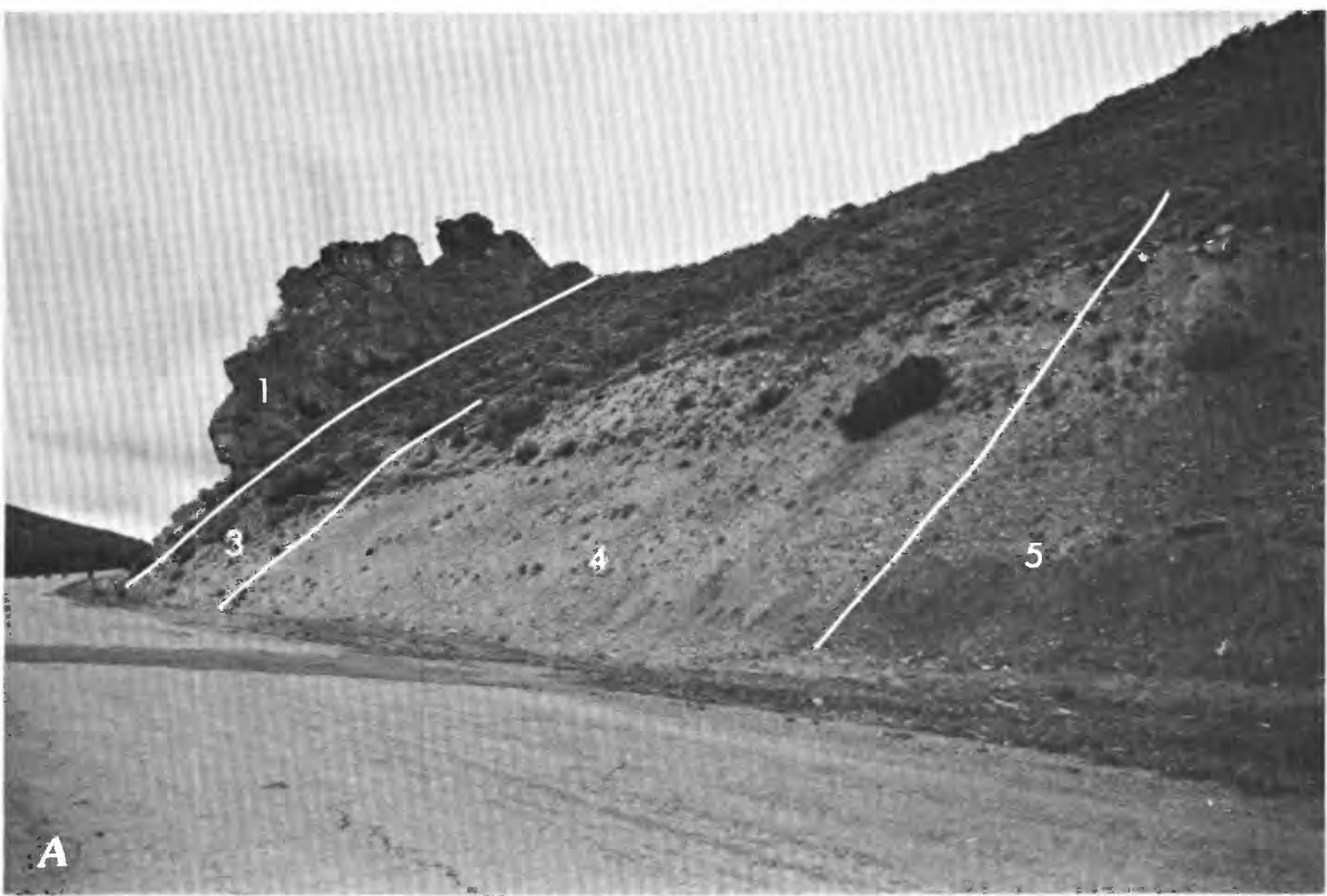

Figure 15.-Stump Formation on old U.S. Highway 30 near Evanston, Wyo. (loc. 17, fig. 6). A, westward view of entire section. $B$,

1, Ephraim Conglomerate; 2, Redwater Member, sandstone unit; 3, shale unit;

Section 6.-Tincup Creek-Continued

Stump Formation-Continued

Redwater Member-Continued

Sandstone unit-Continued

1. Sandstone, thick- to medium-bedded, gray, ripple-marked; basal beds not exposed

Thickness Curtis Member

Thickness of Stump Formation

$\frac{55}{100}$

Preuss Sandstone (not examined).

Section 7.-Stump Peak

[Principal reference section: Stump Formation on peak, about $1.6 \mathrm{~km}$ northwest of Stump Peak, near center of NE1/4 sec. 7. T. 6 S. R. 45 E. Freedom quadrangle, Caribou County, Idaho. Strata are overturned, dip $25^{\circ} \mathrm{W}$. See figure 10]

Ephraim Conglomerate (incomplete):

3. Siltstone, pale-red, sandy

Stump Formation:

Curtis Member:

Shale unit:

2. Claystone, limy, sandy near base, contains gray limestone concretions, soft, gray, makes slope . 15.2
Section 7.-Stump Peak-Continued

Thickness (meters)

Stump Formation-Continued

Curtis Member-Continued Sandstone unit:

1. Sandstone, thin- to medium-bedded, and sandy shale, gray, ripple-marked; bears tracks and trails; makes cliffs and ledges 61.0

Thickness of Stump Formation 76

Preuss Sandstone eroded from top of peak.

\section{Section 8-Stump Creek}

[Reference section: Stump Formation on north side of Stump Creek about $3.2 \mathrm{~km}$ west of Auburn. Wyo., in E1/2NW1/4 sec. 26, T. 7 S., R. 46 E., Freedom quadrangle, Caribou County, Idaho. See figure 11]

Ephraim Conglomerate (incomplete):

4. Siltstone, pale-red, sandy $3+$

Stump Formation:

Curtis Member:

Shale unit:

3. Claystone, soft. with thin interbeds of platy, ripple-marked sandstone that bear trails, and 


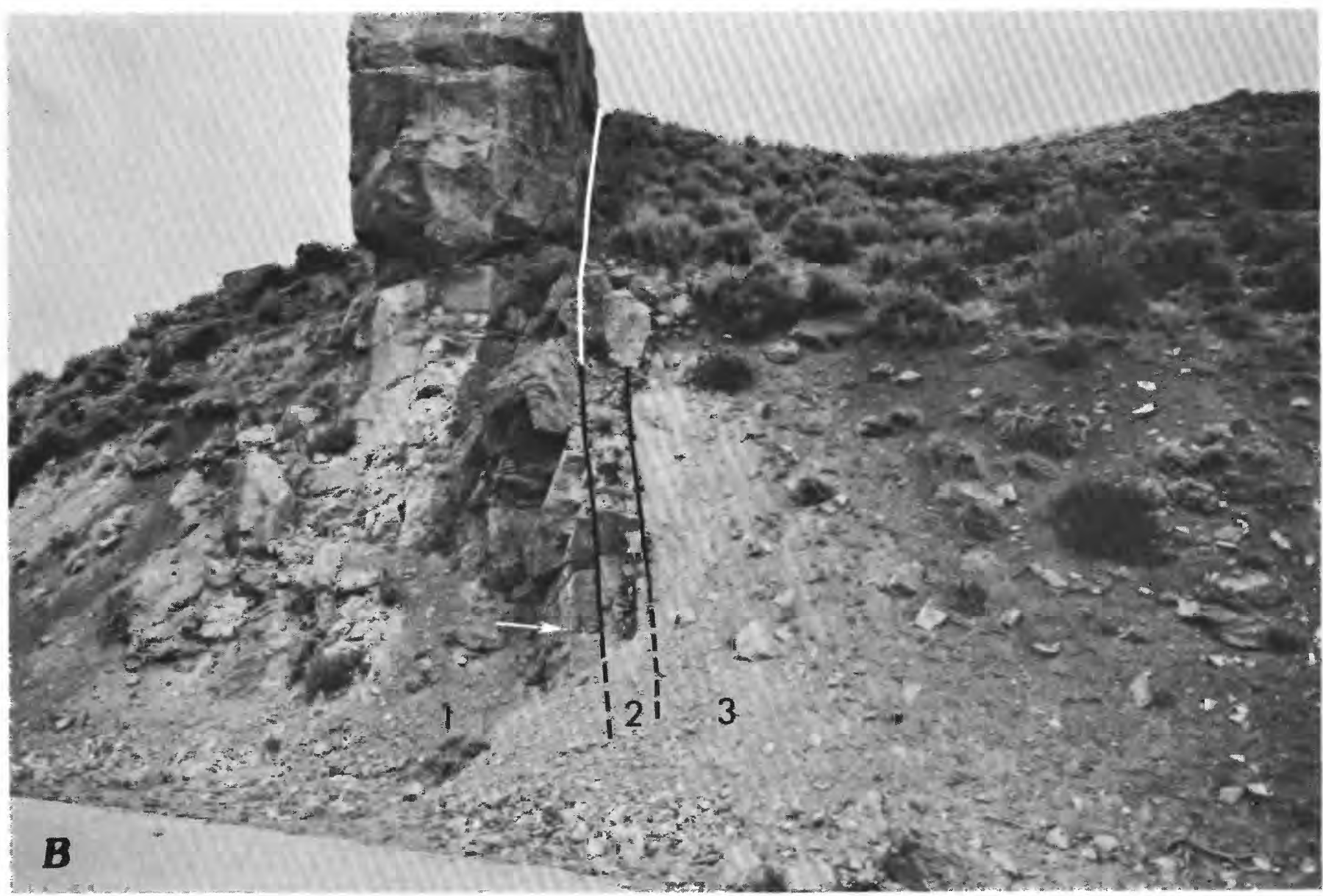

northward view of upper part of the Redwater Member in contact with conglomęratic beds in the lower part of the Ephraim Conglomerate.

4, Curtis Member, shale unit; 5, Preuss Sandstone. Arrow points to hammer for scale.

Section 8.-Stump Creek-Continued

Stump Formation-Continued

Curtis Member-Continued

Shale unit-Continued

shaly limestone; contains light-gray limestone concretions and some fossiliferous oolitic slabs found as float on claystone 30.5

Sandstone unit:

2. Sandstone, thick- to thin-bedded, cliff-forming at base; becomes shaly upward; contact with Preuss poorly exposed but appears to be moderately sharp

Thickness of Stump Formation 100

Preuss Sandstone (incomplete):

1. Sandstone, thin-bedded, very fine grained, grayish-red, calcareous, locally contains gypsum and chert nodules, makes ledgy slope

\section{Section 9.-Telephone Creek}

[Reference section: Stump Formation on west side of creek of Telephone Hollow about $0.8 \mathrm{~km}$ north of Deadman Creek, near center of SE1/4 sec. 29, T. 25 N., R. 116 W.. Afton quadrangle, Lincoln County, Wyo. See figure 12]

Thickness

(meters)

Ephraim Conglomerate (incomplete):

6. Sandstone, gray to pinkish-gray

$3+$

Stump Formation:

Redwater Member:

Sandstone unit:

5. Covered ….................................................... 18.3

4. Sandstone, massive, cliff-forming, glauconitic, gray

................................................................ 11.3

3. Sandstone, silty, shaly to thin-bedded, gray ........ 9.1

2. Sandstone, medium- to thick-bedded, cliffforming, glauconitic, yellowish-gray, some crossbedding; contains belemnites, oysters, and Camptonectes; rests sharply on underlying unit 15.8 Thickness of Redwater Member 55 


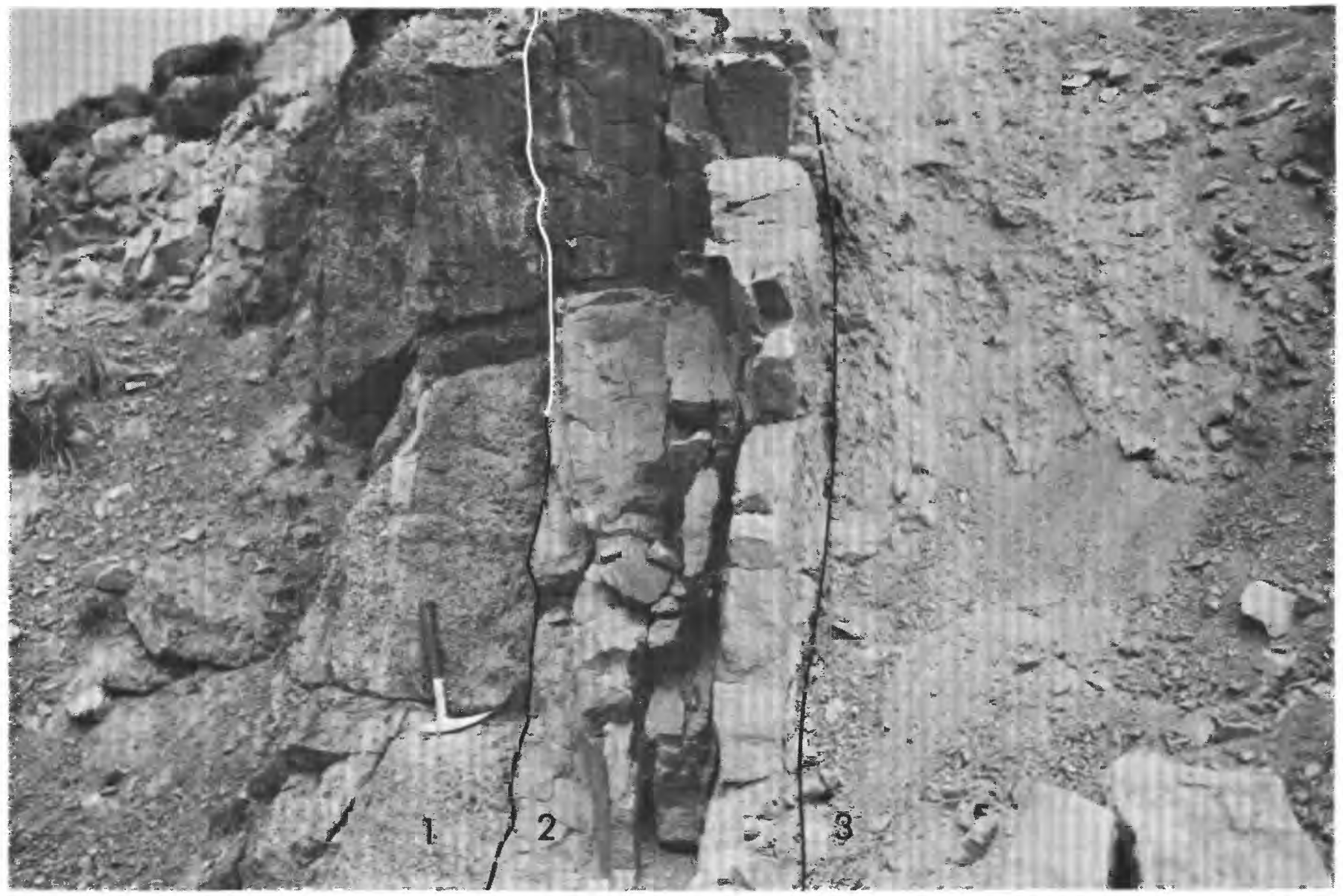

Figure 16.- Near view of contacts shown in figure 15B. The hammer is on the lowest bed in the Ephraim Conglomerate. Note minor channeling at contact. The hammer is about 33 centimeters long. 1, Ephraim Conglomerate; 2, Redwater Member of Stump Formation, sandstone unit; 3, Redwater Member, shale unit.

Section 9.-Telephone Creek-Continued

$$
\text { Thickness }
$$

(meters)

Stump Formation-Continued

Curtis Member:

Sandstone unit:

1. Sandstone, silty sandstone, yellowish-gray, shaly to thin-bedded, ripple-marked; has irregular wavy bedding; grades downward into red Preuss Sandstone

Thickness of Stump Formation

$\frac{11.3}{66}$

Preuss Sandstone (not examined).

\section{Section 10.-Sheep Creek}

[Stump Formation near intersection of Sheep Creek and Greys River in W1/2 sec. 4. T. 33 N.. R. 116 W., Afton quadrangle, Lincoln County, Wyo. See figure 13]

Ephraim Conglomerate (incomplete):

8. Claystone, soft, red and green; contains nodules of limestone; probably of Early Cretaceous age ...

Stump Formation:

Redwater Member:
Section 10.-Sheep Creek-Continued

Thickness

(meters)

Stump Formation-Continued

Redwater Member-Continued

Sandstone unit:

7. Sandstone thin-to medium-bedded, very fine grained; greenish-gray; contains furrowed trails; grades into underlying beds; forms low cliffs ... 13.7

6. Limestone, thick-bedded, oolitic, glauconitic, sandy, yellowish-gray; contains a few thin beds; belemnites and Camptonectes present

5. Siltstone, sandy, massive, medium-gray, nonfissile; makes slope

Shale unit (?):

4. Limestone, sandy, and limy sandstone, fine-grained, cliff-forming, medium- to dark-gray, glauconitic; some oolitic beds containing oysters in topmost $0.3 \mathrm{~m}$; belemnites present at basal contact and higher; rests sharply on underlying unit 
Section 10.-Sheep Creek-Continued

\section{Thickness}

(meters)

Stump Formation-Continued

Curtis Member:

Shale unit:

3. Shale, fissile; weathers into pencil-like flakes; some very thin platy sandstone interbeds, medium-gray; rests conformably on thin beds of green tuff

Sandstone unit:

2. Sandstone and siltstone, red .............................. 2.4

1. Sandstone, silty, and sandy siltstone, gray $\quad \ldots \ldots \ldots . . . . \quad 3.7$

Thickness of Curtis Member .................. 9

Thickness of Stump Formation ............ 43

Preuss Sandstone (not examined).

$$
\text { Section 11.-Shale Creek }
$$

[Stump Formation on ridge west of Shale Creek, and north of East Fork of Greys River about 0.4 $\mathrm{km}$ east of its junction with the West Fork of Greys River, NE1/4 sec. 20, T. 30 N., R. 116 W., Afton quadrangle, Lincoln County, Wyo.]

Ephraim Conglomerate (not examined)

Stump Formation:

Redwater Member:

Sandstone unit:

4. Sandstone, cliff-forming, medium- to thin-bedded, greenish-gray, glauconitic; contains one bed of bentonite about $4.9 \mathrm{~m}$ above base; Meleagrinella and Kallirhynchia common in lower part ....... 13.4

Shale unit:

3. Siltstone, soft, brown, clayey at base; contains many belemnites and small, worn specimens of Gryphaea nebrascensis (Meek and Hayden). One bentonite bed occurs $30 \mathrm{~cm}$ below top 4.0

Thickness of Redwater Member 17

Curtis Member:

Sandstone unit:

2. Sandstone, cliff-forming, medium- to thin-bedded, wavy-bedded, ripple-marked, yellowish-gray; rests sharply on underlying unit

Thickness of Stump Formation $\frac{14.3}{32}$

Preuss Sandstone (incomplete):

1. Sandstone, red, thin-bedded; makes steep ledgy slope .

Section 12.-Fish Creek

[Stump Formation near Fish Creek along U.S. Highway 89 a bout $9.6 \mathrm{~km}$ south of Smoot in SE1/4 sec. 32 , T. $30 \mathrm{~N}$., R. $118 \mathrm{~W}$., and $\mathrm{E} / 4 \mathrm{sec} .5$, T. $29 \mathrm{~N}$., R. $118 \mathrm{~W}$., Afton quadrangle, Lincoln County, Wyo. See figure [4]

Ephraim Conglomerate (incomplete):

8. Siltstone, pale-red, sandy, partly covered $3+$

Stump Formation:

Curtis Member:

Shale unit:

7. Clay shale, fissile, limy, gray; contains lenticular concretions ranging from several $\mathrm{cm}$ to more than a meter in length. At base is a gray oolitic bed, $5-13 \mathrm{~cm}$ thick, that contains crinoid stems and oysters

6. Clay shale, as above; contains limestone concretions as much as $20 \mathrm{~cm}$ in length. At base is a gray, slightly sandy, oolitic bed from 15 to $20 \mathrm{~cm}$ thick that contains oysters and crinoid fragments
Section 12.-Fish Creek-Continued

Thichness

(meters)

Stump Formation- Continued

Curtis Member - Continued

Sandstone unit:

5. Sandstone, shaly to very thin bedded; some clay shale and some silty clay shale, gray; bears ripple marks and many tracks and trails

4. Shale, sandy, gray, green, and red, ripple-marked; bears tracks and trails

3. Siltstone, red, about $3 \mathrm{~m}$ thick; becomes reddish gray in top $1.6 \mathrm{~m}$; barren of tracks and trails; resembles the Preuss Sandstone .................... 4.6

2. Shale, sandy, and shaly sandstone, gray to greenish-gray, ripple-marked; contains a few reddish zones

1. Sandstone, medium- to thin-bedded to shaly, very fine grained, gray, slightly glauconitic; ripple-marked; forms low cliffs; lower 0.9-1.2 m covered

Thickness of Stump Formation

Preuss Sandstone (not examined).

\section{Section 13.-Salt Canyon}

[Stump Formation on west side of Salt Canyon south of Packstring Creek, SW1/4SE1/4 sec. 27. T. 29 N., R. 1 I9 W., Salt Flat quadrangle, Lincoln County, Wyo.]

Ephraim Conglomerate (incomplete)

4. Siltstone, pale-red, sandy, clayey $3+$

Stump Formation:

Curtis Member:

Sandstone unit:

3. Sandstone, gray and greenish-gray, fine- to medium-grained, limy, thin-bedded, ripple-marked; bears many tracks and trails; contains many clayey siltstone partings; makes ledgy slope

2. Sandstone, gray and greenish-gray, very fine to fine-grained, medium-bedded, ripple-marked; makes ridge

Thickness of Stump Formation

Preuss Sandstone (Mansfield, 1927, p. 99)

Section 14.- La Barge Creek

[Stump Formation on ridge north of La Barge Creek in north-central part of sec. 17, T. 27 N., R. 15 W., Coal Creek quadrangle, Sublette County, Wyo.]

Ephraim Conglomerate (incomplete):

5. Basal part consists of $\mathrm{I} \mathrm{m}$ of sandy limestone underlain by $1.1 \mathrm{~m}$ of bright-green shaly sandstone that rests sharply on underlying unit

Stump Formation:

Redwater Member:

Sandstone unit:

4. Sandstone, calcareous, glauconitic, massive, cliff-forming, mostly light gray to brownish-gray; basal $1.8 \mathrm{~m}$ weathers white, fragments of carbonized wood common throughout 
Section 14.-La Barge Creek-Continued

Stump Formation--Continued

Redwater Member--Continued

Shale unit:

3. Shale, silty to finely sandy, gray; bears two thin beds of bentonite; basal part contains belemnites and worn fragments of Griphaea nehrascensis (Meek and Hayden)

Thickness of Redwater Member

Curtis Member:

Sandstone unit:

2. Sandstone, thin- to medium-bedded, light-gray: forms top of low cliff

1. Sandstone, shaly and sandy siltstone, light-gray; some beds as much as $2.5 \mathrm{~cm}$ thick; wavy bedding common; grades downward gradually into red sandstone at top of Preuss Sandstone . 9.3

Thickness of Curtis Member 11

Thickness of Stump Formation

Preuss Sandstone (Imlay, 1950, p. 41)

\section{Section 15.-Fort Hill}

[Stump Formation on ridge west of Dutch George Creek and about $3.2 \mathrm{~km}$ west-northwest of Fort Hill in N W1/4.NE $1 / 4$ SE $1 / 4$ sec. 3. T. 25 N.. R. 115 W., Fort Hill quadrangle. Lincoln County. Wyo.]

Ephraim Conglomerate (covered, soil is grayish red).

Stump Formation:

Redwater Member:

Sandstone unit:

5. Sandstone, medium- to thin-bedded, flaggy, white; some soft siltstone partings; upper contact covered

4. Sandstone and sandy coquinoid limestone, medium- to thin-bedded, greenish-gray, highly glauconitic; some partings of soft siltstone; some beds as much as $0.6 \mathrm{~m}$ thick; contains ammonites and belemnites in basal bed

Shale unit:

3. Claystone, chunky, limy, alternating with blocks of chunky limestone, yellowish-gray; contains belemnites in basal $15 \mathrm{~cm}$

Curtis Member:

Thickness of Redwater Member

er $\ldots \ldots \ldots \ldots \ldots \ldots . . . \cdots, \frac{3}{26}$

Shale unit:

2. Clay shale, flaky, olive-green; contains limestone concretions. Upper contact with Redwater Member is marked by concretionary blocks that bear oysters

Sandstone unit:

1. Sandstone, cliff-forming, yellowish-gray, thick- to thin-bedded, some shaly interbeds, medium- to fine-grained, ripple-marked; wavy bedding common; thicker beds contain much glauconite. Contact with red Preuss Sandstone as exposed on road $1.6 \mathrm{~km}$ north of measured section is marked by $15-30 \mathrm{~cm}$ of white bentonite

Thickness of Curtis Member $\frac{10}{11}$

Thickness of Stump Formation

Preuss Sandstone (not examined).
Section 16.-Watton Canyon

[Stump Formation on north side of Watton Canyon near center W1/2 sec. 26. I. 9 N.. R. 5 E.. Meachum Ridge quadrangle. Rich County, Utah]

Wasatch Formation (incomplete):

2. Interbedded brownish-red sandy clay shale, siltstone, and sandy claystone

Stump Formation:

Curtis Member:

Sandstone unit:

1. Sandstone, greenish-gray, coarse-grained to conglomeratic, thick- to medium-bedded, with thin sandy claystone partings. Pentacrinus columnals are common throughout: Iower part makes ridge; basal contact poorly exposed

Total thickness of Stump Formation .......

Preuss Sandstone (not examined).

Section 17.-Evanston

[Stump Formation on north side of old U.S. Highway 30 (abandoned) in NW1/4 SW1/4SW1/4 sec. 18. T. I5 N., R. 118 W.. about $17.6 \mathrm{~km}$ east of Evanston, Guild Hollow quadrangle, Uinta County. Wyo. See figures 15 and 16$]$

Ephraim Conglomerate (incomplete):

11. Basal conglomerate stands vertically and forms a high cliff

Stump Formation:

Redwater Member:

Sandstone unit:

10. Sandstone, medium-bedded, medium-grained, cross bedded, highly glauconitic, grayish-yellow; contains some brown chert pebbles and the fossils Meleagrinella and Lopha. Contact with Ephraim Conglomerate is sharp and channeled

9. Sandstone, fine-grained, silty, shaly, to very thin bedded, soft, grayish-yellow, glauconitic. A sandstone bed, about $0.3 \mathrm{~m}$ thick, is $1.5 \mathrm{~m}$ above base and contains carbonized wood fragments

Shale unit:

8. Clay shale, chunky, dark-yellowish-gray, mostly covered; a belemnite found $2.4 \mathrm{~m}$ above probable base of Redwater Member

Curtis Member:

Shale unit:

7. Clay shale, flaky, greenish-gray, mostly covered . 15.3

6. Clay shale, flaky, greenish-gray; some beds of platy, fine-grained sandstone $12-25 \mathrm{~mm}$ thick ............ 45.7

5. Sandstone, limy, very thin bedded, wavy-bedded, yellowish-gray, estimated thickness ................ 1.8

4. Clay shale, flaky, soft greenish-gray ................ 8.2

3. Limestone, sandy, thin- to medium-bedded, very fine grained, mostly medium gray; some greenish-gray partings ................................. 0.9

2. Shale, flaky, rests sharply on underlying unit ...... 1.2 Thickness of Curtis Member ................ 73 Thickness of Stump Formation ........... 88

Preuss Sandstone (incomplete):

1. Sandstone, pale-red, fine-grained, thin-bedded; makes soft slope 
Section 18.-Peoa

[Stump Formation northwest of Peoa in SE1/4SW1/4 sec. 11. T. I S., R. 5 E., Kamas quadrangle. Summit County, Utah]

Thickness (meters)

Ephraim Conglomerate (incomplete):

8. Interbedded red and green claystone and gray limestone

Stump Formation:

Redwater Member:

Sandstone unit:

7. Sandstone, cliff-forming, medium-bedded, greenish-gray; upper $1.2 \mathrm{~m}$ consists of sandy limestone and bears fragments of oysters and other bivalves

6. Siltstone, sandy, greenish-gray ...................... 4.6

Shale unit:

5. Clayey to finely sandy siltstone, greenish-gray; one bentonite bed at top; base not exposed ...........

4. Covered (probably contains contact between Redwater and Curtis Members) 4.6 Thickness of Redwater Member

Curtis Member:

Shale unit (incomplete):

3. Clay shale, flaky; gray top not exposed 29.3 Sandstone unit:

2. Sandstone, platy, thin- to medium-bedded, crossbedded, wavy-bedded, medium-grained, yellowish-gray; basal contact poorly exposed .. 12.5

Thickness of Curtis Member $\frac{42}{67}$

Preuss Sandstone:

1. Sandstone and siltstone, grayish-red; makes slope (Thomas and Krueger, 1946, p. 1282)

\section{REFERENCES CITED}

Albee, H. F., 1968, Geologic map of the Munger Mountain quadrangle, Teton and Lincoln Counties, Wyoming: U.S. Geol. Survey Geol. Quad. Map GQ-705.

Baker, A. A., 1947, Stratigraphy of the Wasatch Mountains in the vicinity of Provo, Utah: U.S. Geol. Survey Oil and Gas lnv. Prelim. Chart 30.

Cressman, E. R., 1964, Geology of the Georgetown Canyon-Snowdrift Mountain area, southeastern Idaho: U.S. Geol. Survey Bull. 1153, 105 p.

Gardner, L. S., 1944, Phosphate deposits of the Teton Basin area, Idaho and Wyoming: U.S. Geol. Survey Bull. 944-A, p. 1-36.

Gilluly, James, 1929, Geology and oil and gas prospects of part of the San Rafael Swell, Utah: U.S. Geol. Survey Bull. 806-C, p. 69-130.

Gilluly, James, and Reeside, J. B., Jr., I928, Sedimentary rocks of the San Rafael Swell and some adjacent areas in eastern Utah: U.S. Geol Survey Prof. Paper 150-D, p. 61-110.

Hansen, W. R., 1965, Geology of the Flaming Gorge area, Utah-Colorado-Wyoming: U.S. Geol. Survey Prof. Paper 490, 196 p.
Imlay, R. W., 1950, Jurassic rocks in the mountains along the west side of the Green River Basin, in Wyoming Geol. Assoc. Guidebook 5th Ann. Field Conf., Southwest Wyoming, 1950: p. 37-48.

1952, Marine origin of Preuss sandstone of Idaho, Wyoming, and Utah: Am. Assoc. Petroleum Geologists Bull., v. 36, no. 9, p. 1735-I753.

1967, Twin Creek Limestone (Jurassic) in the western interior of the United States: U.S. Geol. Survey Prof. Paper 540, 105 p.

Mansfield, G. R., 1927, Geography, geology, and mineral resources of part of southeastern Idaho, with Descriptions of Carboniferous and Triassic fossils, by G. H. Girty: U.S. Geol. Survey Prof. Paper 152, 453 p.

1952, Geography, geology, and mineraI resources of the Ammon and Paradise Valley quadrangles, Idaho: U.S. Geol. Survey Prof. Paper 238, 92 p. [1953].

Mansfield, G. R., and Roundy, P. V., 1916, Revision of the Beckwith and Bear River formations of southeastern Idaho: U.S. Geol. Survey Prof. Paper 98-G, p. 75-84.

Oriel, S. S., 1963, Preliminary geologic map of the Fort Hill quadrangle, Lincoln County, Wyoming: U.S. Geol. Survey Oil and Gas Inv. Map OM-212.

Pampeyan, E. H., Schroeder, M. L., Schell, E. M., and Cressman, E. R., 1967, Geologic map of the Driggs quadrangle, Bonneville and Teton Counties, Idaho, and Teton County, Wyoming: U.S. Geol. Survey Mineral Inv. Field Studies Map MF-300.

Pipiringos, G. N., and O'Sullivan, R. B. 1978, Principal unconformities in Triassic and Jurassic rocks, western interior United States-a preliminary survey: U.S. Geol. Survey Prof. Paper 1035-A, 29 p. (in press).

Rubey, W. W., 1958, Geology of the Bedford quadrangle, Wyoming: U.S. Geol. Survey Geol. Quad. Map GQ-109.

1973, Geologic map of the Afton quadrangle and part of the Big Piney quadrangle, Lincoln and Sublette Counties, Wyoming: U.S. Geol. Survey Misc. Geol. Inv. Map I-686.

Rubey, W. W., Oriel, S. S., and Tracey, J. I., Jr., 1975, Geology of the Sage and Kemmerer 15-minute quadrangles, Lincoln County, Wyoming: U.S. Geol. Survey Prof. Paper 855, I8 p.

Schroeder, M. L., 1969, Geologic map of the Teton Pass quadrangle, Teton County, Wyoming: U.S. Geol. Survey Geol. Quad. Map GQ-793.

Staatz, M. H., and Albee, H. F., 1963, Preliminary geologic map of the Garns Mountain SE quadrangle, Bonneville and Teton Counties, Idaho: U.S. Geol. Survey Mineral Inv. Field Studies Map MF-262.

1966, Geology of the Garns Mountain quadrangle, Bonneville, Madison, and Teton Counties, Idaho: U.S. Geol. Survey BulI. 1205 , $122 \mathrm{p}$.

Stokes, W. L., 1944, Morrison Formation and related deposits in and adjacent to the Colorado Plateau: Geol. Soc. American Bull., v. 55, no. 8 , p. 951-992.

1955, Non-marine Late Jurassic and Early Cretaceous Formations, in Wyoming Geol. Assoc. Guidebook 10th Ann. Field Conf., 1955: p. 80-84.

Thomas, H. D., and Krueger, M. L., 1946, Late Paleozoic and early Mesozoic stratigraphy of Uinta Mountains, Utah: Am. Assoc. Petroleum Geologists Bull., v. 30, no. 8, p. 1255-1293.

Vine, J. D., 1959, Geology and uranium deposits in carbonaceous rocks of the Fall Creek area, Bonneville County, Idaho: U.S. Geol. Survey Bull. 1055-I, p. 255-294 [1960].

Wanless, H. R., Belknap, R. L., and Foster, H. L., 1955, Paleozoic and Mesozoic rocks of Gros Ventre, Teton, Hoback, and Snake River Ranges, Wyoming: Geol. Soc. America Mem. 63, 90 p. 



\section{Unconformities, Correlation, and Nomenclature of Some Triassic and Jurassic Rocks, Western Interior United States}

GEOLOGICAL SURVEY PROFESIONAL PAPER 1035

This volume was published

as separate chapters $A-C$
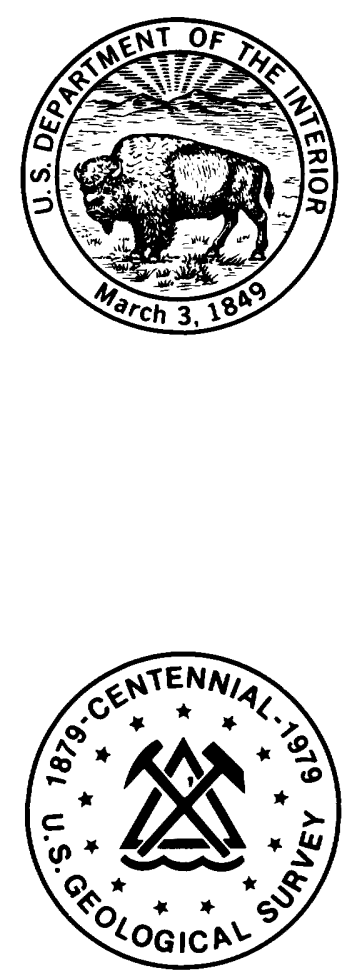



\section{CONTENTS}

[Letters designate the separately published chapters]

(A) Principal unconformities in Triassic and Jurassic rocks, Western Interior United States - A preliminary survey, by George N. Pipiringos and Robert B. O'Sullivan.

(B) Stratigraphic relations of the Navajo Sandstone to Middle Jurassic formations, southern Utah and northern Arizona, by Fred Peterson and George N. Pipiringos.

(C) Lithology and subdivisions of the Jurassic Stump Formation in southeastern Idaho and adjoining areas, by George N. Pipiringos and Ralph W. ImIay. 


